\title{
強震記録から評価した短周期震源スペクトルの地域性
}

\author{
鹿島小堀研究室* 加 藤 研一・武 村 雅 之 \\ 東京電力** 八 代 和 彦
}

\section{Regional Variation of Source Spectra in High-frequency Range Determined from Strong Motion Records}

\author{
Kenichi Kato and Masayuki Takemura \\ Kobori Research Complex, Kajima Corporation, 6-5-30, \\ Akasaka, Minato-ku, Tokyo 107-8502, Japan \\ Kazuhiko Y ASHIRo \\ Tokyo Electric Power Company, 1-1-3, Uchisaiwai-cho, \\ Chiyoda-ku, Tokyo 100-0011, Japan
}

(Received September 8, 1997; Accepted May 20, 1998)

\begin{abstract}
We examine the excitation strengths of source spectra in high-frequency range, and discuss their regional variation. Target events are subduction earthquakes off Fukushima Prefecture, intermediate depth earthquakes in the Kanto region, and shallow earthquakes in the southern Kanto region in Japan. The analyzed data are S-wave portions of 672 accelerograms from 40 events observed at 27 stations in the southern Tohoku and the Kanto region. Source spectra are evaluated by simultaneously separating source, propagation path, and local site effects using inversion technique in spectral domain [IwAta and Irikura (1986)]. The magnitude of these events ranges from 3.8 to 7.0, and hypocentral distance from 20 to $200 \mathrm{~km}$. First of all, the relationship between the seismic moment $M_{0}$ and the amplitude of source spectra in high-frequency range $M_{H F}$ is examined. $M_{H F}$ is evaluated by taking logarithmic average of acceleration source spectrum from 1 to $10 \mathrm{~Hz}$. $M_{H F}$ is nearly proportional to $M_{0}^{1 / 3}$, which is expected from the scaling of source spectra based on $\omega^{-2}$ model. $M_{H F}$ shows regional variation even if $M_{0}$ is nearly equal. To quantitatively estimate the amplitude difference in high-frequency range, BRUNE stress drop $\Delta \sigma$ [BRUNE $(1970,1971)]$ is evaluated for each event using $M_{0}$ and $M_{H F}$. Average $\Delta \sigma$ for shallow earthquakes in the southern Kanto, subduction earthquakes off Fukushima Prefecture, and intermediate depth earthquakes in the Kanto region is about 100 bars, 200 bars, and 370 bars, respectively. Taking into account the relation that $M_{H F}$ is proportional to $\Delta \sigma^{2 / 3}$, intermediate depth earthquakes excite about 2.4 times larger amplitude than that for shallow earthquakes in high-frequency range. Thus, deeper events generally show large $\Delta \sigma$ in comparison with shallower events, suggesting that the focal depth is a key parameter to control the excitation strengths of source spectra in high-frequency range.
\end{abstract}

Key words: Source spectra, High-frequency, Regional variation, Strong motions.

\section{§1.はじめに}

震源が励起する短周期波動は, 断層面上のすべりや応 力の不均質性に強く支配されている[例えば，小山 (1983)]. 従って, 短周期波動の励起強さを地震の発生地 域ごとに調べ, 破壊過程の特徵を明らかにすることは地

* 干 107-8502 東京都港区赤坂 6-5-30

** $=100-0011$ 東京都千代田区内幸町 1-1-3
震学上の重要な研究テーマである，また，木造や中低層 建物の固有周期が $1 \mathrm{~Hz}$ 以上であることを考えると, 短 周期波動の励起強さの地域差を明らかにし, 地震危険度 評価等に反映させていくことは, 都市防災の観点からも 重要である.

地震は発生地域に応じて特徵的な波動を励起すること は既に指摘されている。例えば, KANAMORI (1972)は, 
海溝軸の内側の縁に沿う帯状地帯に，通常の地震に比べ て低周波成分の振幅が非常に大きく，津波の励起を伴う 地震が発生することを明らかにした. 武村・小山 (1983) はモーメントファクター $M_{e}$ と特徽周期 $T_{c}$ [KoYAMA $e t$ al. (1982)] を用いて $M_{e} / T_{\mathrm{c}}^{3}$ から低周波地震を定義し, 津 波を発生させるような比較的規模の大きい地震だけでな く, 中小規模の地震でも海溝軸の内側の縁に沿って低周 波地震が発生することを示した。これらの研究は地震 モーメントとコーナー周期等の断層の平均的な破壊を記 述するパラメータを用いており，いわば長周期領域にお ける震源過程の地域性を論じたものである.

一方, 短周期領域における震源の地域性は, 長周期領 域に比べて研究例が少ない，その原因として，短周期波 動は波長が短く，伝播経路の不均質性や表層地盤の増幅 の影響を受けやすいことが挙げられる. UTSU (1980) お よび宇佐美・他 (1992) は, 気象庁マグニチュードと震 度分布から算定されるマグニチュードの差から低周波地 震之高周波地震を定義し，その空間分布について論じて いる.これらの研究は, 過去の被害地震から現在に至る 豊富なデータを広域な範用で利用できる利点があるもの
の, 震度やマグニチュードという経験的な尺度を介した 短周期成分の評価である. 震源が励起する短周期波動の 地域性をより詳細に調べるには, 地震波形の解析が必要 と思われる.

観測波形を用いて短周期震源スペクトルの地域性を示 した例として, 武村・他 (1989) による茨城〜福島県沖 のプレート境界地震の検討がある. 武村・他 (1989) は 1983 年から 1987 年に観測された近地加速度記録の分 析から, 福島県沖は高周波地震が発生する地域とそうで ない地域に別れ，その境界の中心は太平洋プレートの潜 り込みの上面でほぼ $40 \mathrm{~km}$ 付近にあると指摘している. 武村・他 (1989) が対象とした地震はプレート境界地震 であるが, やや深発地震やプレート内の浅い地震も, 発 生位置により地域性を示すのであろうか. また, やや深 発地震や浅い地震の短周期波動の励起強さは, プレート 境界地震に比べてどの程度異なるのであろうか. これら の課題を同質のデータと手法を用いて統一的に検討した 例は少ないと思われる.

そこで, 本研究は福島県沖のプレート境界地震, 関東 直下のやや深発地震, および南関東の浅い地震の加速度

Table 1. Origin time, epicenter, magnitude $M$, and focal depth $D$ determined by JMA, and seismic moment $M_{0}$ determined by DzIEwonski and his colleague. Units of $D, M_{0}$ are $\mathrm{km}$ and $10^{23} \mathrm{dyne} \cdot \mathrm{cm}$. $M_{H F}$ indicates amplitude of source spectra evaluated by taking logarithmic average of inverted acceleration source spectra from 1 to $10 \mathrm{~Hz}$. Unit of $M_{H F}$ is $10^{23} \mathrm{dyne} \cdot \mathrm{cm} / \mathrm{sec}^{2} . \Delta \sigma$ is BRUNE stress drop [BRUNe $(1970,1971)]$ with unit of bars. (a) subduction earthquakes off Fukushima Prefecture, (b) intermediate depth earthquakes in the Kanto region, and (c) shallow earthquakes in the southern Kanto region.

(a) Subduction earthquakes [Tohoku]

\begin{tabular}{rrrrrrrrrrr} 
Eq. No. & \multicolumn{1}{c}{ Date } & & Lat. & Log. & $M$ & \multicolumn{1}{c}{$D$} & $M_{\ell}$ & $M_{H F}$ & $\Delta \sigma$ \\
\hline \hline F1 & 82 & 307 & $8: 14$ & 36.5 & 140.7 & 5.5 & 60 & 18 & 525 & 154 \\
F2 & 82 & 723 & $23: 23$ & 36.2 & 142.0 & 7.0 & 30 & 3920 & 6152 & 419 \\
F3 & 83 & 702 & $7: 03$ & 36.9 & 141.2 & 5.8 & 54 & 35 & 1206 & 385 \\
F4 & 83 & 1116 & $19: 44$ & 37.3 & 141.7 & 5.3 & 39 & 11 & 261 & 69 \\
F5 & 84 & 326 & $3: 59$ & 37.3 & 141.7 & 5.2 & 42 & 6 & 480 & 234 \\
F6 & 84 & 1219 & $4: 35$ & 37.1 & 141.6 & 5.3 & 44 & 8 & 743 & 389 \\
F7 & 85 & 812 & $12: 49$ & 37.7 & 141.9 & 6.4 & 52 & 575 & 2582 & 298 \\
F8 & 86 & 212 & $11: 59$ & 36.4 & 141.1 & 6.1 & 44 & 248 & 890 & 92 \\
F9 & 86 & 1014 & $6: 17$ & 37.1 & 141.2 & 5.7 & 52 & 30 & 794 & 222 \\
F10 & 87 & 206 & $21: 23$ & 36.9 & 141.9 & 6.4 & 30 & 436 & 1267 & 117 \\
F11 & 87 & 206 & $22: 16$ & 37.0 & 141.9 & 6.7 & 35 & 1329 & 2641 & 203 \\
F12 & 87 & 407 & $9: 40$ & 37.3 & 141.9 & 6.6 & 44 & 1142 & 5132 & 592 \\
F13 & 87 & 417 & $4: 23$ & 37.0 & 141.7 & 6.1 & 45 & 142 & 537 & 57 \\
F14 & 87 & 423 & $5: 13$ & 37.1 & 141.6 & 6.5 & 47 & 1081 & 2338 & 187 \\
F15 & 87 & 1004 & $19: 27$ & 37.3 & 141.7 & 5.8 & 42 & 36 & 1175 & 365 \\
F16 & 89 & 1209 & $2: 23$ & 36.6 & 141.1 & 5.6 & 46 & 29 & 500 & 113 \\
F17 & 92 & 511 & $19: 08$ & 36.5 & 140.5 & 5.6 & 56 & 10 & 428 & 152 \\
\hline
\end{tabular}

(b) Intermediate depth earthquakes [Kanto]

\begin{tabular}{crrrrrrrrrr}
\hline Eq. No. & \multicolumn{1}{c}{ Date } & & Lat. & Lon. & $M$ & \multicolumn{1}{c}{$D$} & $M_{0}$ & $M_{H F}$ & $\Delta \sigma$ \\
\hline \hline D1 & 80 & 924 & $4: 10$ & 36.0 & 139.8 & 5.4 & 80 & 12 & 724 & 306 \\
D2 & 80 & 925 & $2: 54$ & 35.5 & 140.2 & 6.1 & 80 & 130 & 2665 & 656 \\
D3 & 83 & 227 & $21: 14$ & 35.9 & 140.2 & 6.0 & 72 & 78 & 1177 & 249 \\
D4 & 85 & 1004 & $21: 25$ & 35.9 & 140.2 & 6.1 & 78 & 87 & 1879 & 476 \\
D5 & 85 & 1106 & $0: 30$ & 35.4 & 140.2 & 5.0 & 62 & - & - & - \\
D6 & 86 & 624 & $11: 53$ & 34.8 & 140.7 & 6.5 & 73 & 939 & 3435 & 357 \\
D7 & 87 & 417 & $16: 33$ & 35.7 & 140.1 & 5.1 & 77 & 6 & 280 & 107 \\
D8 & 87 & 1217 & $11: 08$ & 35.4 & 140.5 & 6.7 & 58 & 705 & 3341 & 394 \\
D9 & 88 & 318 & $5: 34$ & 35.7 & 139.7 & 6.0 & 96 & 31 & 1684 & 675 \\
D10 & 88 & 812 & $14: 14$ & 35.1 & 139.9 & 5.3 & 69 & 6 & 752 & 454 \\
D11 & 90 & 605 & $22: 43$ & 35.6 & 139.2 & 5.4 & 122 & 11 & 577 & 228 \\
D12 & 92 & 202 & $4: 04$ & 35.2 & 139.8 & 5.9 & 92 & 55 & 1942 & 628 \\
\hline
\end{tabular}

\begin{tabular}{|c|c|c|c|c|c|c|c|c|c|c|}
\hline Eq. No. & & Date & & Lat. & Lon. & $M$ & $D$ & $M_{0}$ & $M_{H F}$ & $\Delta \sigma$ \\
\hline S1 & 80 & 629 & $16: 20$ & 34.9 & 139.2 & 6.7 & 10 & 472 & 1525 & 149 \\
\hline S2 & 82 & 812 & $13: 33$ & 34.9 & 139.6 & 5.7 & 30 & 42 & 314 & 47 \\
\hline S3 & 83 & 808 & $12: 47$ & 35.5 & 139.0 & 6.0 & 22 & 37 & 669 & 154 \\
\hline S4 & 88 & 905 & $0: 49$ & 35.5 & 139.0 & 5.6 & 30 & 12 & 357 & 106 \\
\hline S5 & 88 & 929 & $17: 23$ & 35.9 & 139.2 & 5.0 & 15 & - & 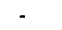 & - \\
\hline S6 & 88 & 930 & $2: 39$ & 35.9 & 139.2 & 4.5 & 15 & - & - & - \\
\hline S7 & 88 & 1112 & $11: 18$ & 35.9 & 139.2 & 3.8 & 19 & - & - & - \\
\hline S8 & 89 & 709 & 11:09 & 35.0 & 139.1 & 5.5 & 3 & 8 & 149 & 35 \\
\hline S9 & 89 & 1014 & $6: 19$ & 34.8 & 139.5 & 5.7 & 21 & 13 & 807 & 346 \\
\hline S10 & 90 & 220 & $15: 53$ & 34.8 & 139.2 & 6.5 & 6 & 433 & 976 & 80 \\
\hline S11 & 91 & 1124 & 21:07 & 36.1 & 139.3 & 4.1 & 21 & - & - & - \\
\hline
\end{tabular}


記録からインバージョンにより震源スペクトルを各々求 め, 地震の発生地域により短周期波動の励起強さがどの 程度異なるかについて検討する。

\section{§ 2. 解析対象の地震と強震観測点}

東北南部・関東地方の強震観測点で得られた加速度記 録を基にして, Table 1(a)〜 (c) に示す 3 つのデータセッ トを構築した. データセット 1 は茨城から福島県沖のプ レート境界で発生した深さ 30〜60 km の地震であり,

TAKEMURA et al. (1991) および KATo et al. (1992) が用 いたデータに, 1988 年以降の記録を追加したものであ る. また, 武村・他 (1989) の検討に用いられた地震も含 まれている. データセット 2 は関東直下で発生した深さ $60 \mathrm{~km}$ 以深のやや深発地震である. KinOSHITA (1992) は関東直下で発生する地震を 6 種類に分類している. データセット 2 は Kinoshita による分類の S2 と S3 に 対応し, フィリピン海プレートと太平洋プレートが衝突 して発生する深さ 50-80 km の地震, およびフィリピン 海プレート下面と太平洋プレート上面に発生する $70 \mathrm{~km}$ より深い地震である. データセット 3 は南関東
で発生した深さ $30 \mathrm{~km}$ 以浅の地震である.この地震は KINOSHITA による分類の S4 と S5 に対応し，アジアプ レート内に発生する $20 \mathrm{~km}$ より浅い地震とフィリピン 海プレートがアジアプレートに衝突して発生する地震で ある. データセット 1 は 17 地震, 2 は 12 地震, 3 は 11 地震を解析対象とした. これらの地震の選定にあたって は, 原則として地震モーメントと震源メカニズム解が求 められていることを条件とした. ただし，データセット 3 はこの条件を満たす地震が少ないため, その他の地震 あ解析対象に含めた。

検討に用いた強震記録は, 10 電力共通研究による 9 観測点, 電力中央研究所による 4 観測点, 港湾技術研究 所による 9 観測点, 鹿島技術研究所による 4 観測点, 東 京大学生産技術研究所による 1 観測点の計 27 地点で得 られた 672 成分であり, 地点名と観測機関および表層地 質を Table 2 に示す. 鈶直アレー観測が実施されている 地点は，原則として地表と地中最深部の記録を用いた. 震央と観測点位置を Fig. 1 に, 気象庁マグニチュードと 震源距離の関係を Fig. 2 に示す. Fig. 1 には, IsHIDA (1992) により推定されたフィリピン海プレート上面ま

Table 2. Observation stations used in this study.

\begin{tabular}{|c|c|c|c|c|c|c|c|c|}
\hline Station name & Latitude & Longitude & Depth & Abr. & Sampling $[\mathrm{Hz}]$ & Geological period & Institution* & Event number recorded \\
\hline Tomioka & $\mathrm{N} 37^{\circ} 20^{\prime}$ & $\mathrm{E} 141^{\circ} 00^{\circ}$ & $\begin{array}{l}\text { GL } 0 \mathrm{~m} \\
\text { GL }-100 \mathrm{~m} \\
\text { GL }-950 \mathrm{~m}\end{array}$ & $\begin{array}{l}\text { TMK6 } \\
\text { TMK4 } \\
\text { TMK1 }\end{array}$ & $\begin{array}{c}200 \\
.\end{array}$ & Neogene & $\begin{array}{c}\text { CSMIA } \\
.\end{array}$ & $\begin{array}{c}\text { F3 - F17 } \\
-\end{array}$ \\
\hline Iwaki & $\mathrm{N} 37^{\circ} 05^{\prime}$ & $\mathrm{E} 140^{\circ} 53^{\prime}$ & $\begin{array}{l}\text { GL } 0 \mathrm{~m} \\
\text { GL }-21 \mathrm{~m} \\
\text { GL }-330 \mathrm{~m}\end{array}$ & $\begin{array}{l}\text { IWK6 } \\
\text { IWK5 } \\
\text { IWK1 }\end{array}$ & $\dot{\bullet}$ & Paleogene & $\dot{.}$ & $\begin{array}{c}\mathrm{F} 1-\mathrm{F} 16 \\
\cdot\end{array}$ \\
\hline Kodamagawa & $\mathrm{N} 37^{\circ} 07^{\prime}$ & $\mathrm{E} 140^{\circ} 50^{\circ}$ & $\mathrm{GL}-10 \mathrm{~m}$ & KDG & - & Cretaceous & - & F7- F17 \\
\hline Idegawa & $\mathrm{N} 37^{\circ} 19^{\prime}$ & $\mathrm{E} 140^{\circ} 57^{\prime}$ & GL $0 \mathrm{~m}$ & IDG & • & Cretaceous & • & F6, F8 - F11, F13 - F15, F17 \\
\hline Hokidaira & $\mathrm{N} 37^{\circ} 14^{\prime}$ & $\mathrm{E} 140^{\circ} 55^{\prime}$ & GL $0 \mathrm{~m}$ & HKD & & Cretaceous & - & F6, F8 - F9, F12 - F14, F17 \\
\hline Oharai & $\mathrm{N} 36^{\circ} 20^{\prime}$ & $\mathrm{E} 140^{\circ} 36^{\prime}$ & GL $-14 m$ & OAR & 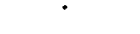 & Cretaceous - Paleogene & • & F7 - F14, F16-F17 \\
\hline Choshi & $\mathrm{N} 35^{\circ} 43^{\prime}$ & $\mathrm{E} 140^{\circ} 52^{\prime}$ & GL $-18 m$ & CHS & 100 & Cretaceous & • & $F 1-F 3, F 8, F 10-F 12, F 14$ \\
\hline Higashi-Matsuyama & $\mathrm{N} 36^{\circ} 00^{\prime}$ & $\mathrm{E} 139^{\circ} 23^{\prime}$ & $\begin{array}{l}\text { GL } 0 m \\
\text { GL }-121 m\end{array}$ & $\begin{array}{l}\text { HMY6 } \\
\text { HMY1 }\end{array}$ & $\dot{\bullet}$ & Neogene & $\dot{\bullet}$ & D1 - D4, D6 - D9, D11 - D12, S1 - S7, S10 - S11 \\
\hline Ogawa & $\mathrm{N} 36^{\circ} 01^{\prime}$ & $\mathrm{E} 139^{\circ} 17^{\prime}$ & GL $-11 \mathrm{~m}$ & OGW & 200 & Cretaceous & $\cdot$ & D4, D6, D9, D12, S4 - S7, S11 \\
\hline Namie & $\mathrm{N} 37^{\circ} 30^{\prime}$ & $\mathrm{E} 141^{\circ} 02^{\prime}$ & GL $0 \mathrm{~m}$ & NME & 100 & Neogene & CRIEPI & F2 - F3, F6 - F7, F9 - F14 \\
\hline Kidogawa & $\mathrm{N} 37^{\circ} 17^{\prime}$ & E140 $57^{\prime}$ & GL $0 \mathrm{~m}$ & KID & & Cretaceous & & F6 - F7, F9 - F14 \\
\hline Nakaminato & $\mathrm{N} 36^{\circ} 20^{\prime}$ & $\mathrm{E} 140^{\circ} 36^{\prime}$ & GL $0 \mathrm{~m}$ & NKM & • & Cretaceous - Paleogene & • & F2, F11-F12, F14 \\
\hline Mihodo & $\mathrm{N} 37^{\circ} 28^{\prime}$ & $\mathrm{E} 140^{\circ} 52^{\prime}$ & GL $0 \mathrm{~m}$ & MHD & & Cretaceous & $\cdot$ & F9 - F14 \\
\hline Kashima-Zhokan-S & $\mathrm{N} 35^{\circ} 56^{\prime}$ & $\mathrm{E} 140^{\circ} 41^{\prime}$ & GL $0 \mathrm{~m}$ & KSM-S & 100 & Diluvial & PHRI & F2 - F3, F8, F11, F16 \\
\hline Onahama-Zi-S & $\mathrm{N} 36^{\circ} 56^{\circ}$ & E $140^{\circ} 55^{\circ}$ & GL $0 \mathrm{~m}$ & ONH-S & & Neogene & $\cdot$ & F2 - F3, F8 - F9, F12, F14 \\
\hline Soma-S & $\mathrm{N} 37^{\circ} 50^{\prime}$ & $\mathrm{E} 140^{\circ} 58^{\prime}$ & GL $0 \mathrm{~m}$ & SMA-S & - & Neogene & • & F7, F9-F12, F14-F15 \\
\hline Hitachinaka-S & $\mathrm{N} 36^{\circ} 23^{\prime}$ & $\mathrm{E} 140^{\circ} 37^{\prime}$ & GL $0 m$ & HTN-S & & Diluvial & • & F9-F13, F16 \\
\hline Chiba-S & N35 $34^{\prime}$ & $\mathrm{E} 140^{\circ} 06^{\prime}$ & GL $0 \mathrm{~m}$ & CBA-S & & Alluvial & • & D2 - D6, D8 \\
\hline Shinagawa-S & $\mathrm{N} 35^{\circ} 37^{\prime}$ & $\mathrm{E} 139^{\circ} 46^{\circ}$ & GL $0 m$ & SHN-S & & Alluvial & • & D1 - D6, D8 - D10 \\
\hline Keihin-Zi-S & $\mathrm{N} 35^{\circ} 27^{\prime}$ & $\mathrm{E} 139^{\circ} 38^{\prime}$ & GL $0 \mathrm{~m}$ & KHN-S & * & Alluvial & • & D2 - D4, D6, D8 - D10, S1 - S3, S9 - S10 \\
\hline Yamashitahen-S & $\mathrm{N} 35^{\circ} 27^{\prime}$ & $\mathrm{E} 139^{\circ} 40^{\prime}$ & GL $0 \mathrm{~m}$ & YMH-S & 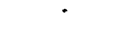 & Alluvial & • & D1 - D4, D6, D8 - D9 \\
\hline Yamashitahen-M & $\mathrm{N} 35^{\circ} 27^{\prime}$ & $\mathrm{E} 139^{\circ} 40^{\prime}$ & GL $0 \mathrm{~m}$ & YMH-M & & Alluvial & $\cdot$ & D1 - D4, D6, D8 - D10, S4, S9 - S10 \\
\hline Ohji & $\mathrm{N} 35^{\circ} 46^{\prime}$ & $\mathrm{E} 139^{\circ} 44^{\circ}$ & GL $-30 m$ & OHJ & 100 & Alluvial & KATRI & D2, D9 - D11, S4 - S6, S8 - S10 \\
\hline Shiinamachi & $\mathrm{N} 35^{\circ} 44^{\prime}$ & $\mathrm{E} 139^{\circ} 41^{\prime}$ & GL $-27 m$ & SIN & & Alluvial & & S2 - S6, S8 \\
\hline Tobitakyu & $\mathrm{N} 35^{\circ} 39^{\prime}$ & $\mathrm{E} 139^{\circ} 32^{\prime}$ & $\begin{array}{l}\text { GL }-01 m \\
\text { GL }-51 m\end{array}$ & $\begin{array}{l}\text { TBT2 } \\
\text { TBT1 }\end{array}$ & $\dot{*}$ & Alluvial & $\dot{*}$ & D4, D7 - D10, S4 - S9 \\
\hline Kodaira & $\mathrm{N} 35^{\circ} 44^{\prime}$ & $\mathrm{E} 139^{\circ} 30^{\prime}$ & GL $0 \mathrm{~m}$ & KDR & 200 & Alluvial & - & D4, D6 - D10, D12, S4, S10 - S11 \\
\hline Chiba-Array & $\mathrm{N} 35^{\circ} 37^{\prime}$ & $\mathrm{E} 140^{\circ} 07^{\prime}$ & $\begin{array}{l}\mathrm{GL}-01 \mathrm{~m} \\
\mathrm{GL}-40 \mathrm{~m}\end{array}$ & $\begin{array}{l}\text { CHB2 } \\
\text { CHB1 }\end{array}$ & 200 & Alluvial & EDME & D3 - D5, D8 - D10 \\
\hline
\end{tabular}

(*) CSMIA: "Committee of Strong-Motion Instruments Array" sponsored by ten electric power companies in Japan, 


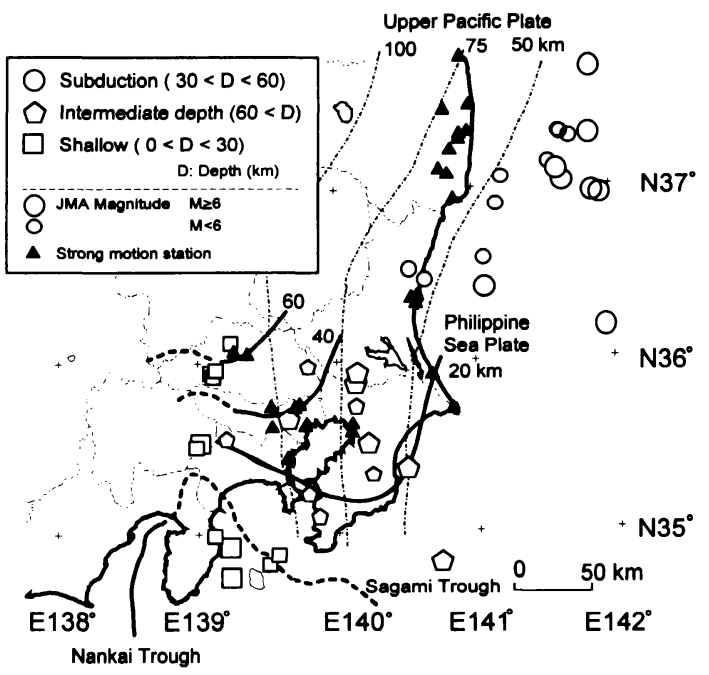

Fig. 1. Strong-motion stations and epicenters of analyzed events. The solid triangles indicate the locations of stations. The open circles, pentagons, and squares indicate the epicenters of subduction earthquakes, intermediate depth earthquakes, and shallow earthquakes, respectively, corresponding to the events listed in Tables 1(a), (b), and (c). Upper boundary of Pacific Plate (Umino and Hasegawa, 1982) and Philippine Sea Plate (IsHidA, 1992) are also depicted.

での深さ (MODEL-91) および，海野・長谷川 (1982)に よる太平洋プレート上面までの深さも示した，震源から 観測点に至る地下構造は伝播経路特性に大きな影響を与 えることが予想される．3つのプレートが会合する関東 地方は伝播経路が複雑であり, 特に注意深く観測点を選 定する必要がある．そこで，むぐり込む海洋プレートの 影響を出来る限り共通にするために, 関東地方の観測点 は関東平野内とその周辺に限定した。

次に地震計の計器特性であるが, 港湾技術研究所の観 測点（Table 2 で-S の表記のある地点）は SMAC-B2 型 加速度計を使用している．SMAC-B2 はスタイラス紙に 引摇き記録する機械式地震計であるため, $1 \mathrm{~Hz}$ から 振幅が低下し始め, $10 \mathrm{~Hz}$ では振幅が約 $1 / 3$ に低下する [例えば, 土田・他 (1967)]. そこで, SMAC-B2 の記 録に対しては計器補正 [Sugito (1993)] を行った。 その 他の地点はデジタル型観測システムを使用しており [Architectural Institute of Japan (1992), 澤田 -他 (1991)，震災予防協会 (1993), 表 -大沢 (1980), 表 (1983)]，少なくとも $0.5 \sim 20 \mathrm{~Hz}$ の周波数帯域でほぼ平 坦な感度・位相差特性を有しているため, 計器補正は行 わなかった。

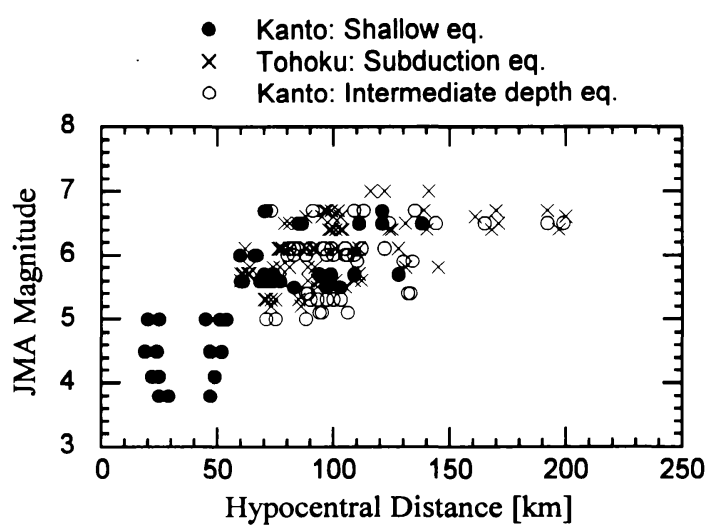

Fig. 2. JMA magnitudes versus hypocentral distances of the analyzed events.

\section{§3. 解析手法}

観測記録のフーリエスペクトルから震源・伝播・地盤 增幅特性を分離するために, 振動数領域の線形インバー ジョン解析［岩田・入倉 (1986)］を実施した.

先ず，加速度フーリエスペクトル $O_{i j}(f)$ を，断層モデ ルの無限遠方近似解に伝播経路の $Q_{s}$ 值による減衰効果 と, 観測点近傍の地盤增幅率 $G_{j}(f)$ を考慮して $(1)$ 式の 形でモデル化する.

$$
O_{i j}(f)=S_{i}(f) \frac{1}{R_{i j}} \exp \left(-\frac{\pi R_{i j} f}{V_{s} Q_{s}(f)}\right) G_{j}(f)
$$

ここで $S_{i}(f)$ は加速度震源スペクトルを, $R_{i j}$ は $i$ 地震 $j$ 観測点における震源距離を， $V_{s}$ は媒質のせん断波速度 を, $f$ は振動数をそれぞれ示す. (1) 式において $Q_{s}(f)$ 值 は伝播経路に依らず, $G_{j}(f)$ は地震に依存せず, 幾何减衰 は $1 / R$ に従うと仮定した. $V_{s}$ は $3.7 \mathrm{~km} / \mathrm{s}$ と設定した [KATo et al. (1992)]. 震源からの地震波動の放射特性に 関しては， $O_{i j}(f)$ として水平 2 成分のベクトル和を取る ことにより，その影響が極力小さくなるように配慮し た. 未知パラメータ $S_{i}(f), Q_{s}(f), G_{j}(f)$ は, 観測波のフー リエスペクトルと (1) 式の㕵差の二乗和が最小になるよ うに振動数ごとに決定した.

(1) 式は自由度が 1 つ足りないため,この手法から唯 一解を求めるには拘束条件が必要である [岩田・入倉 (1986)].データセット 1 は露頭岩盤観測点 KDG の地 盤增幅率に対し，Fig. 3(a) に示す拘束条件を与えた. KDG 観測点は中世代白严紀に属するせ九断波速度 $2.2 \mathrm{~km} / \mathrm{s}$ の花岡岩上に位置している. この拘束条件は TAKEMURA et al. (1991) が用いた值と同一であり, $5 \mathrm{~Hz}$ 以上の地盤増幅率の低下は, KDG が谷地形に位置する ことに起因する地形効果として解釈されている [Kato et al. (1992), КАто (1994)]. データセット 2 および 3 は 露頭岩盤観測点 OGW の地盤増幅率に対し, Fig. 3(b) に 
示す拘束条件を与えた。 OGW 観測点は古〜中世代に属 するせん断波速度 $2.1 \mathrm{~km} / \mathrm{s}$ の長清釆系結晶片岩上に位置 している．地質年代やせん断波速度から判断すると， $\mathrm{KDG}$ と $\mathrm{OGW}$ は同等の基盤上にあると見なせる.

OGW の拘束条件のみでデータセット 2 と 3 のン バージョンを行ったところ，伝播経路の $Q_{\mathrm{s}}$ 值が負にな る振動数があり, 安定した解が得られなかった．地震之 観測点の組数がデータセット 1 より少なく， $Q_{s}$ 值が求 まりにくいことが原因として挙げられる，そこで，デー 夕セット 2 と 3 の検討では， $Q_{s}$ 值についても Fig. 7 の 白丸で示した拘束条件を与えた。この值は，南関東で発 生した深さ $50 \mathrm{~km}$ 以浅の地震に対して KinoshiTA (1994a) が求めた結果である. また，この $Q_{s}$ 值は関東で 発生した深さ 0〜150 km の地震に対する AKI (1980)の 結果とあほぼ一致しているため [KInOSHITA (1994a)], データセット 2 と 3 に共通して用いた。なお，これらの 拘束条件の妥当性に関しては, 後で議論する.

フーリエスペクトルの計算は， $\mathrm{S}$ 波立ち上がり以降の 地震動を対象とした．先ず， $\mathrm{S}$ 波立ち上がり部分を目視 により読み取り，(2) 式で示す修正ハニングウインドウ $w(t)$ により $\mathrm{S}$ 波部分を波形から取り出した.

$$
\begin{aligned}
w(t) & =0.5(1+\cos (\pi t / T)) & & (0<t<\mathrm{T}) \\
& =0 & & (t<0, t>T)
\end{aligned}
$$

ここで $T$ はウインドウ長さを示し, 断層での破壊時間の
2 倍程度を目安に, $M \geqq 6.0$ の地震は $T=20 \mathrm{~s}, 5.0 \leqq M<$ 6.0 は $T=7 \mathrm{~s}, M<5.0$ は $T=3 \mathrm{~s}$ に設定した. 解析に用 いた強震記録の 1 例を Fig. 4 に示す. 図中の太線はウイ ンドウ長さを示す.

フーリエスペクトルを計算する場合は, 高速フーリエ 変換 $(\mathrm{FFT})$ を用いるのが一般的である. しかし， $N$ を地 震波のステップ数, $\Delta t$ を地震波の時間きざみとし, FFT を用いてスペクトルを計算すると振動数きざみが $\Delta f=$ $1 /(N \Delta t)$ と表され，横軸を対数で表現した場合に低振動 (a) Constraint condition for DS1

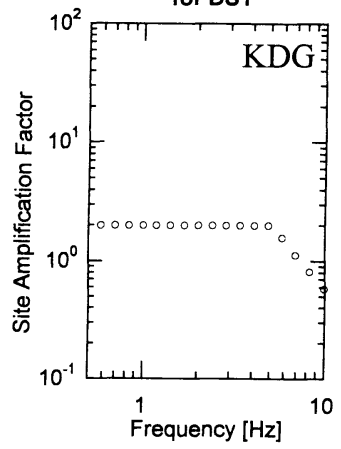

(b) Constraint condition for DS2 and DS3

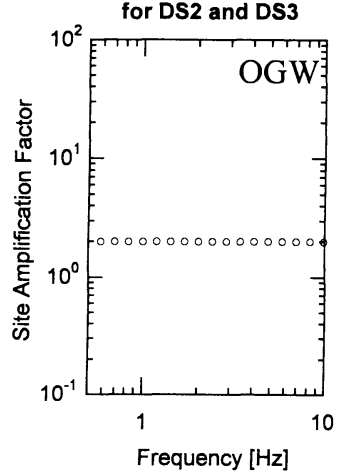

Fig. 3. Site amplification factors at (a) KDG and (b) OGW which are used as a constraint in the inversion analysis.

HMY (GL -0.7m) NS

7.0 $\mathrm{cm} / \mathrm{s} / \mathrm{s}$

0.0

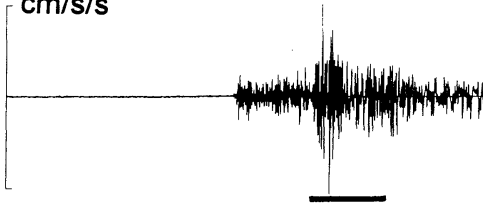

Nov. $12,1988(M=3.8, D=19 \mathrm{~km}, X=29 \mathrm{~km})$

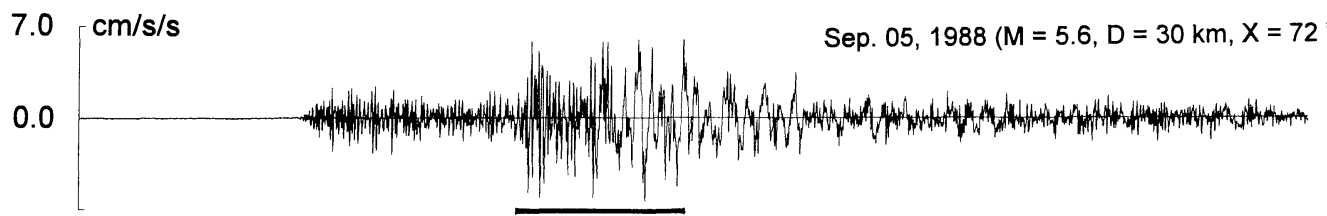

June $29,1980(M=6.7, D=10 \mathrm{~km}, X=121 \mathrm{~km})$

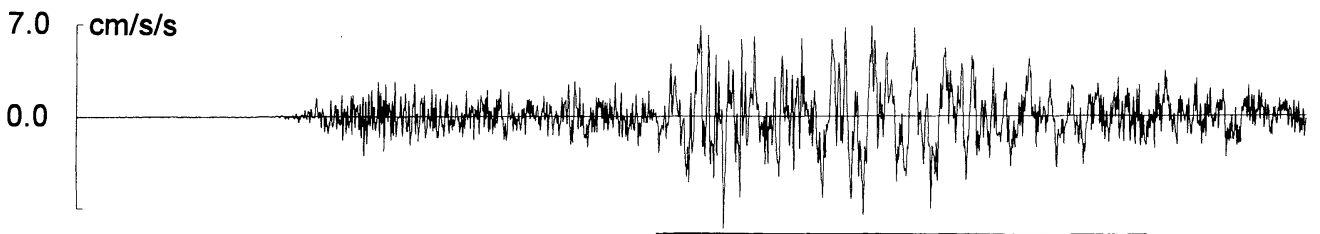

Fig. 4. Examples of NS-component accelerograms observed at HMY for three events with different JMA magnitudes. Horizontal bars indicate the analyzed portions determined by considering the duration time of the faulting. 
数側と高振動数側でスペクトルを描く密度が異なってく る.そこで有限フーリエ変換を用い，対数軸上で振動数 きざみが一定となるようにフーリエスペクトルを求め た、スペクトルを計算した振動数範囲は $0.1 \sim 20.0 \mathrm{~Hz}$ であり, その間を 310 分割した.さらに, 10 個ずつのス ペクトルの対数平均と分散をとり, 対数軸上で振動数き ざみが等間隔な計 31 のスペクトル振幅を得た。スペク トル振幅の分散は, 推定した未知パラメータの誤差評価 に用いた。

最後に，スペクトル振幅の補正について述べる. 修正 ハニングウインドゥを用いたため, 元の波形に対してス ペクトル振幅が過小に評価されている. そこで, 日野 (1977) を参考にして (3) 式によりスペクトル振幅の補正 係数 $\mu$ を求めた.

$$
\mu=\left[\frac{1}{T} \int_{0}^{T} w(t)^{2} d t\right]^{-1 / 2}
$$

(3) 式より $\mu=1.633$ が得られ, 有限フーリエ変換で求ま る振幅を 1.633 倍した值を最終的なスペクトル振幅值 とした．加速度フーリエスペクトルの例として， Fig. 4 に対応する波形のスペクトル振幅とその土1 $\sigma$ を Fig. 5 に示す．デー夕解析で用いたウインドウ長さを配慮し, Fig. 5(a) の $M=3.8$ の地震 は $f>0.3 \mathrm{~Hz}$, Fig. 5(b) の $M=5.6$ の地震は $f>0.15 \mathrm{~Hz}$ のスペクトル振幅のみを示 す. $M=3.8$ のスペクトルは $0.5 \mathrm{~Hz}$ 以下の振動数におい て振幅が左上がりになる傾向が見られるが,この原因 はシグナルが小さく $\mathrm{S} / \mathrm{N}$ が悪いためである. 一方, Fig. 5(c) の $M=6.7$ の地震のスペクトルは全振動数範囲で信 頼できる振幅が得られている. インバージョン解析で は, これらのスペクトルデータを一度に解くため, デー 夕の信頼範囲を考慮して 0.5 $10 \mathrm{~Hz}$ を解析対象とし た. 低振動数側は小地震のウインドウ長さから, 高振動 数側はSMAC-B2 等の計器特性から判断した。なお,
TAKEMURA et al. (1991) は 1 10 Hz を解析範囲とした が, 本研究は比較的マグニチュードが大きい地震のみを 対象としたため, データの信頼範囲を $0.5 \mathrm{~Hz}$ まで拡張 した.

\section{§4. 解析結果}

\section{1 福島県沖のプレート境界地震}

観測スペクトルのインバージョンから得られた加速度 震源スペクトル $S(f)$ を $(4)$ 式を用いて地震モーメント 密度関数 $M(f)$ [KANAMORI (1972)] に変換した.

$$
M(f)=\frac{4 \pi \rho v_{s}^{3} S(f)}{\omega^{2} \mathrm{R}_{\theta \varphi}}
$$

$v_{s}$ は震源における $\mathrm{S}$ 波の速度, $\rho$ は密度, $R_{\theta \phi}$ は震源 のラディエーション係数を示し, $v_{\mathrm{s}}=4.0 \mathrm{~km} / \mathrm{s}, \rho=$ $3.0 \mathrm{~g} / \mathrm{cm}^{3}, R_{\theta \phi}=0.6$ [武村・他 (1989)] と設定した.さ らに, $M(f)$ に $\omega^{2}$ を乗じて加速度に対応する地震モーメ ント密度関数を求め, その振幅と $\pm 1 \sigma$ を 3 地震を例に とり Fig. 6(a) に示す.ここで $\omega^{2} M(f)$ を用いて震源スぺ クトルを表示したのは, 本研究が短周期を対象にしたた めである. 震源のメカニズム解も図中に示したが, これ らはいずれす低角逆断層の地震である.

Fig. 6 の破線は (5) 式に示す $\omega^{-2}$ モデルから予測され る震源スペクトルを示しており, インバージョン結果の スペクトル振幅を解釈する尺度として示した。

$$
\omega^{2} M(f)=\frac{\left(2 \pi f_{c}\right)^{2} M_{0}}{1+\left(f_{c} / f\right)^{2}}
$$

$M_{0}$ は地震モーメントを表し, Table 1 に示した DzIEWONSKI らによる值を用いた. $f_{c}$ はコーナー振動数 を表す. 解析の対象とした振動数範用の制約上, 記録か ら直接 $f_{c}$ を評価するのは難しいため, 以下の $M_{0}-f_{c}$ 関 係 [TAKEMURA et al. (1993)] に $M_{0}$ を代入して推定した. $\log M_{0}=-3 \log f_{c}+23.28$ (a) Nov. 12, 1988 ( $M=3.8)$

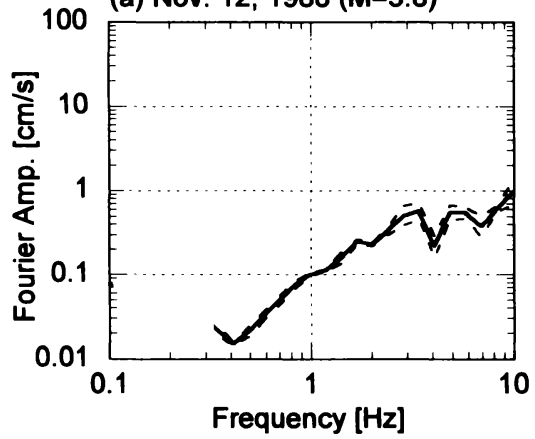

(b) Sep. 05, $1988(M=5.6)$

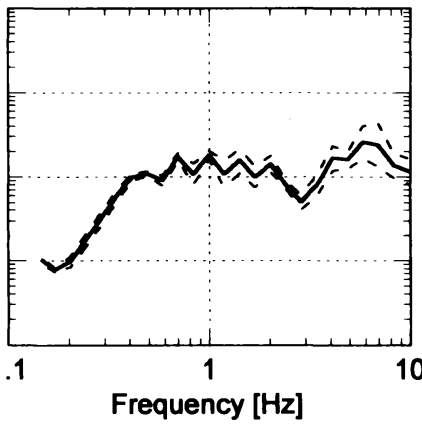

(c) June 29, 1980 (M=6.7)

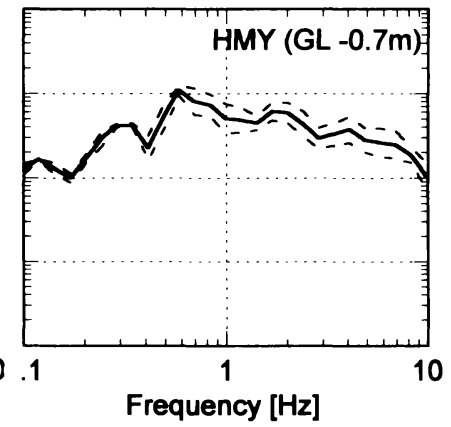

Fig. 5. Examples of Fourier acceleration amplitude spectra at HMY, corresponding to the accelerograms shown in Fig. 4. Dashed lines indicate the standard deviation of the estimated spectra. 


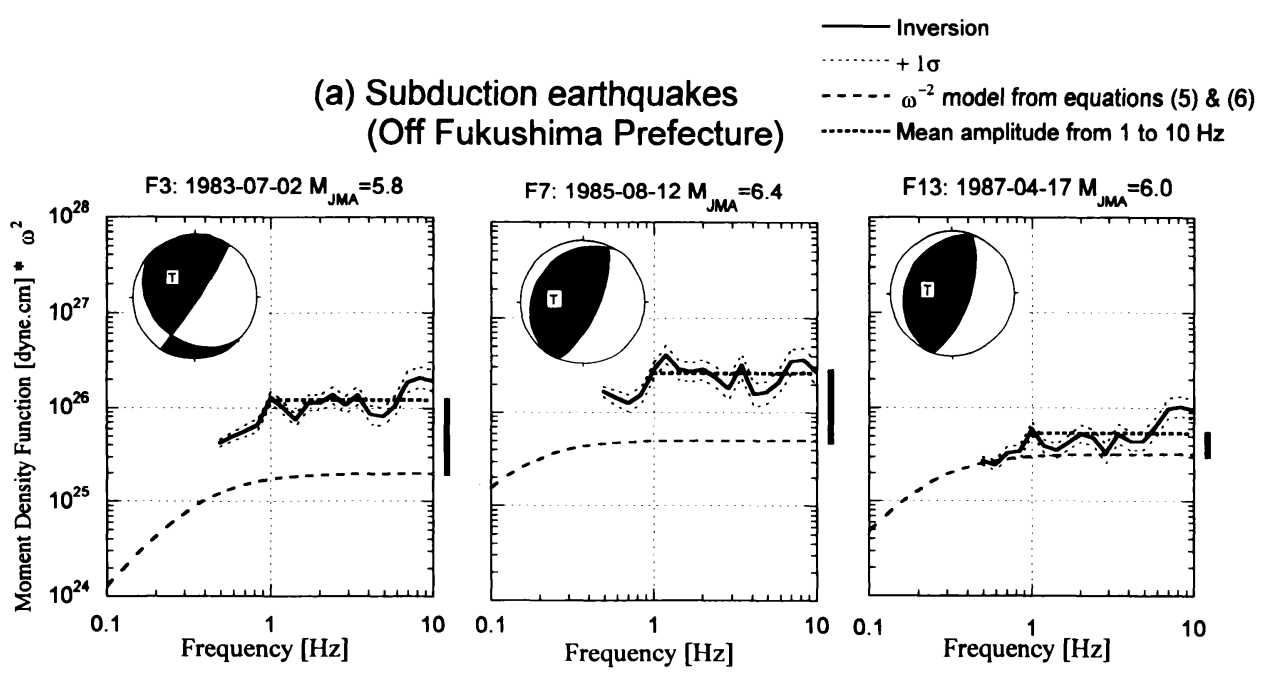

(b) Intermediate depth earthquakes (Kanto region)
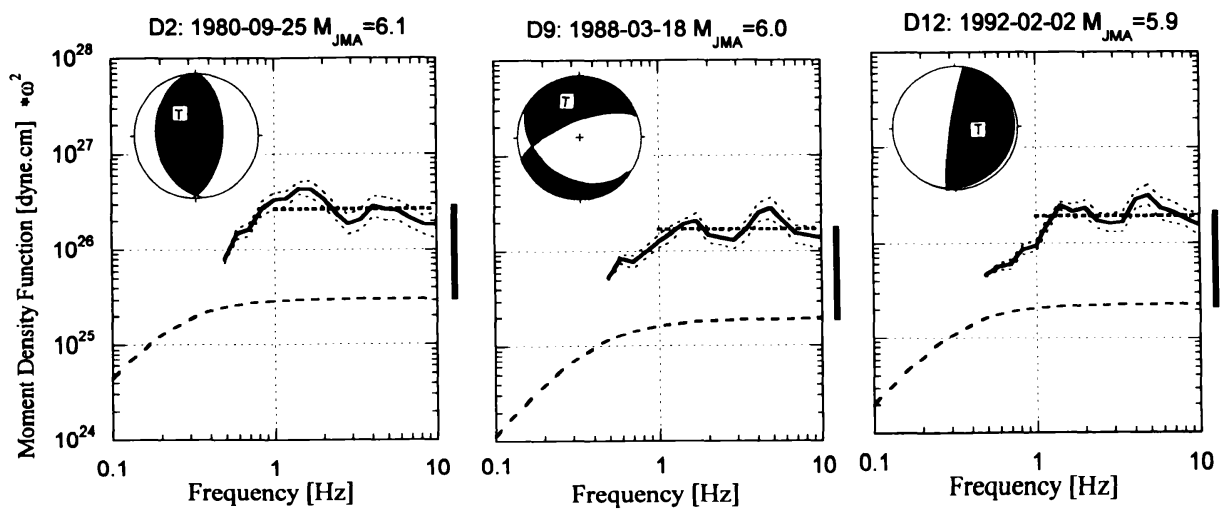

(c) Shallow earthquakes (Southern Kanto region)
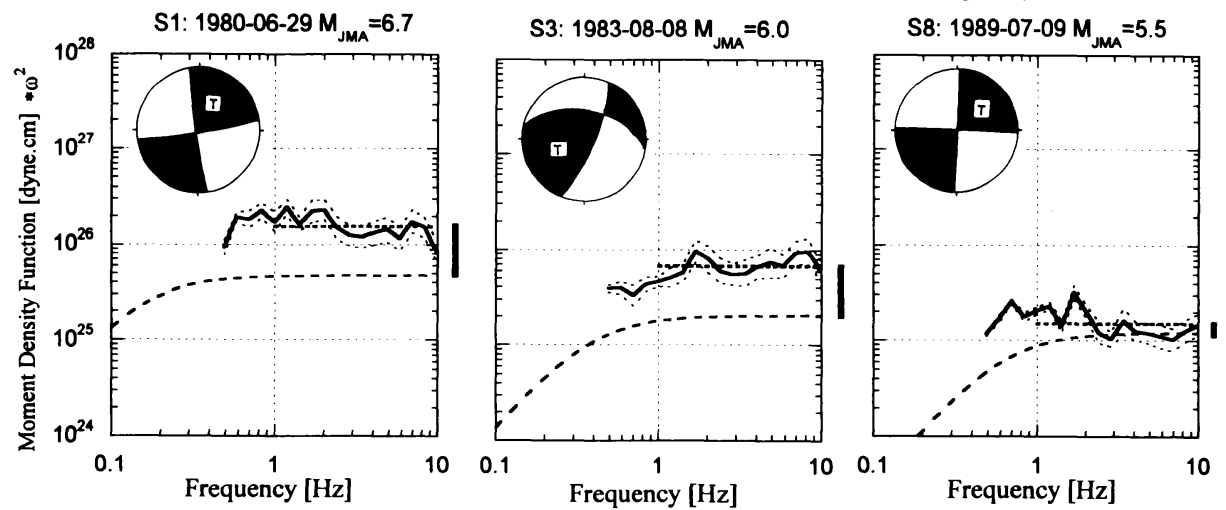

Fig. 6. Some examples of inverted source spectra (solid lines), and their standard deviation (thin dotted lines). Dashed curves denote source spectra expected from $\omega^{-2}$ model using equations (5) and (6). Thick dotted lines denote mean amplitude of inverted source spectra from 1 to $10 \mathrm{~Hz}, M_{H F}$, and vertical solid lines show the difference between $M_{H F}$ and the $\omega^{-2}$ model. Focal mechanism of each event is also shown. (a) subduction earthquakes off Fukushima Prefecture, (b) intermediate depth earthquakes in the Kanto region, and (c) shallow earthquakes in the southern Kanto region. 
上式は，日本における平均的な地震モーメントと断層面 積の関係 [佐藤 (1989)] に, 円形クラックモデルの断層 半径とコーナー振動数の関係 [SATo and HiRASAwa (1973)]を適用して求められている. 従って, (6) 式を(5) 式に代入して求めた $\omega^{-2}$ モデルによるスペクトル振幅 は, 過去に日本で発生した地震の平均的な震源スペクト ルの振幅と見なせる。 なお (6) 式は, 後述するBRUNE の モデル [BRUNE (1970, 1971)] から求まるストレスド ロップ $\Delta \sigma$ を 25 bars とした時の $M_{0}-f_{c}$ 関係に対応し ている.

Fig. 6 には $\omega^{2} M(f)$ の $1 \sim 10 \mathrm{~Hz}$ の短周期振幅を対数 平均した值を短破線で, その平均値と短周期側の $\omega^{-2} €$
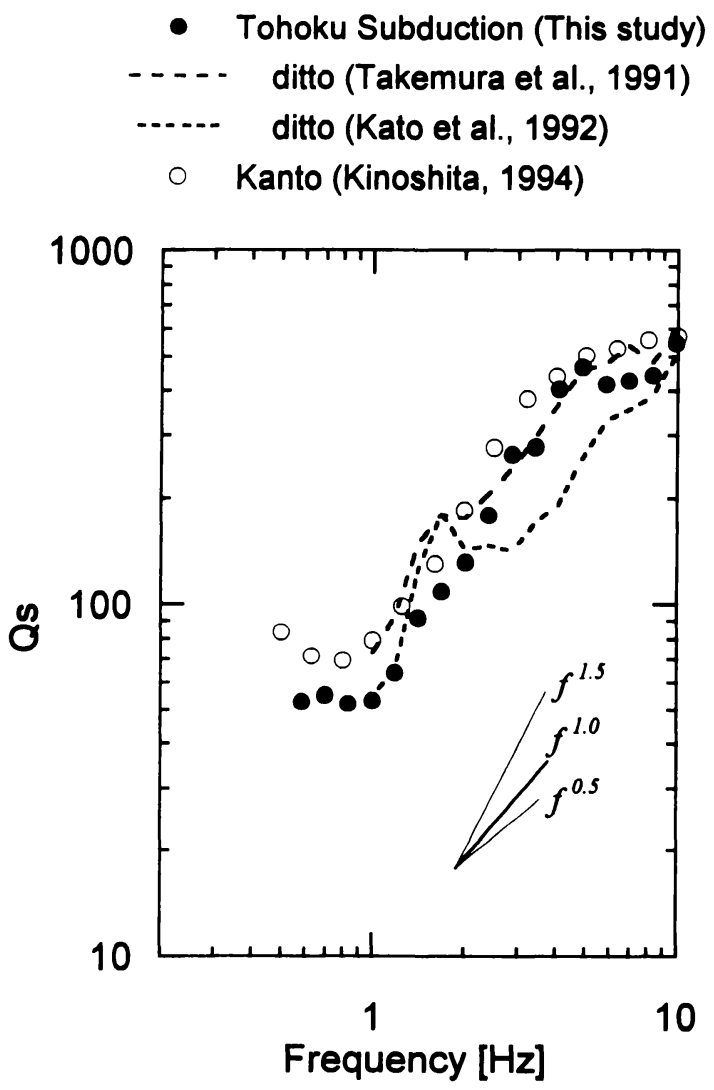

Fig. 7. $Q_{s^{-}}$-values as a function of frequency. Solid circles indicate the $Q_{s}$-value evaluated in this study. Open circles show the result by Kinoshita (1994a) for Kanto region, and are also used as the constraint in the inversion analysis of intermediate depth earthquakes and shallow earthquakes. Dashed and dotted lines denote the results by TAKEMURA et al. (1991) and KATo et al. (1992) for the Pacific coast of southern Tohoku region.
デルとの差を太実線で示した。武村・他 (1989) は福島 県沖の地域は高周波地震が発生する地域とそうでない地 域に分れると指摘している．Fig. 6(a) に示した 3 地震 は, 武村・他 (1989) の分類によれば左から高周波, 中間 および低周波地震と判別されているが, 高周波地震ほど (6) 式から求まる $\omega^{-2}$ モデルより短周期の励起が大き い.

インバージョン結果の伝播経路の $Q$ 值および士 $1 \sigma$ を Fig. 7 と Table 3 に示す. 図中の TAKEMura et al. (1991) および KATo et al. (1992) の結果は, 本研究の データセットを包含する東北地方太平洋岸の $Q$ 值を示 す.これらの $Q$ 值は約 $f^{1.0}$ の振動数依存性を示し, デー 夕セットに依らずほぼ一定の傾向が見られる.一方，Q 值の振幅はやや差があり, 同じ東北地方太平洋岸を扱っ たデータでも TAKEMURA et al. (1991), 本研究, KATO et al. (1992) の順にQ 值は小さくなっている. これらの データセットを比較すると, TAKEMURA et al. (1991) は 仙台の強震観测点など比較的震源距離が遠い記録が含ま れているのに対し, KATo et al. (1992) は福島県以南の 観測点のみを用いている。従って，遠い観測点が含まれ ているデータほよ゙, 地殸およびプレート深部の high-Q の影響が含まれ，Q值が大きくなると推定される．図中 には, Kinoshita (1994a) による南関東の $Q$ 值も比較の ために示した. 福島県沖の $Q$ 值は関東の $Q$ 值よりやや 小さく，伝播経路の減衰が大きいと推測される.

検討に用いた観測点のうち，鉛直アレー観測が実施さ れている IWK と TMK の地盤増幅率を深さ方向の 3 地 点について Fig. 8(a)〜Fig. 8(f) に示す. 太実線が増幅率 を，破線が $1 \sigma$ を表す。両地点では， $V_{s}=3 \mathrm{~km} / \mathrm{s}$ 相当 の地震基盤から地表に至る地下構造が減衰も含めて評価 されており[武村・他 (1993)]，それらの地盤物性を Table 4(a) と Table 4(b) に示す.この地盤モデルを基に して, 地震基盤へ鉛直下方から単位振幅の $S$ 波が入射す る場合の伝達関数を 1 次元波動論を用いて計算し, Fig.

Table 3. Comparison of $Q_{s}$-value with other studies.

\begin{tabular}{cccccc}
\hline $\begin{array}{c}\text { Frequency } \\
{[\mathrm{Hz}]}\end{array}$ & $\begin{array}{c}\text { Qs(f) } \\
\text { This study }\end{array}$ & $\begin{array}{c}\text { Qs(f) } \\
\text { Takemura et al } \\
(199)\end{array}$ & $\begin{array}{c}\text { Qs(f) } \\
\text { Kato et al. } \\
(1992)\end{array}$ & $\begin{array}{c}\text { Frequency } \\
{[\mathrm{Hz}]}\end{array}$ & $\begin{array}{c}\text { Qs(f) } \\
\text { Kinoshita } \\
(1994)\end{array}$ \\
\hline 0.58 & 52.9 & - & - & 0.50 & 83.5 \\
0.70 & 55.0 & - & - & 0.63 & 71.3 \\
0.83 & 52.0 & - & - & 0.80 & 69.3 \\
1.00 & 53.3 & 72.8 & 54.3 & 1.80 & 79.1 \\
1.19 & 63.9 & 91.8 & 65.4 & 1.25 & 98.8 \\
1.41 & 91.7 & 150.0 & 126.1 & 1.60 & 130.6 \\
1.69 & 108.9 & 180.1 & 182.1 & 2.00 & 185.5 \\
2.01 & 131.7 & 175.7 & 143.0 & 2.50 & 277.8 \\
2.40 & 179.5 & 204.7 & 147.1 & 3.20 & 380.2 \\
2.87 & 264.9 & 242.8 & 142.0 & 4.00 & 440.5 \\
3.42 & 278.7 & 295.0 & 171.0 & 5.00 & 505.1 \\
4.08 & 404.0 & 368.1 & 191.4 & 6.30 & 529.1 \\
4.87 & 467.1 & 457.8 & 257.6 & 8.00 & 558.7 \\
5.81 & 418.0 & 476.9 & 327.6 & 10.00 & 571.4 \\
6.93 & 427.8 & 540.1 & 353.5 & 12.50 & 653.6 \\
8.27 & 441.4 & 481.6 & 385.3 & 16.00 & 840.3 \\
9.87 & 547.2 & 590.7 & 500.6 & & \\
\hline
\end{tabular}




\section{Iwaki Down-hole Array Station}

Inversion

$+1 \sigma$

1-D Theory
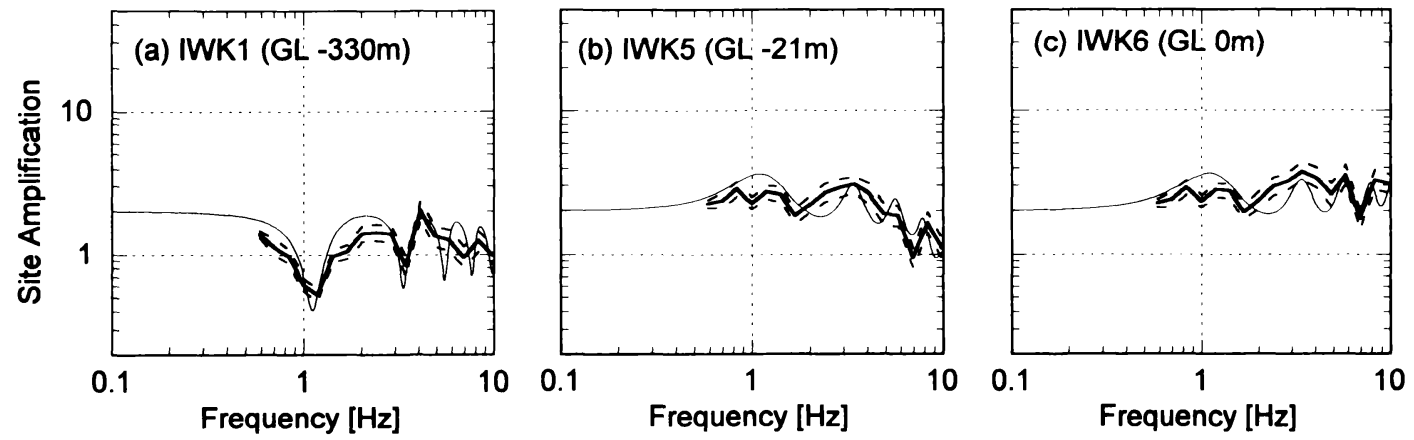

\section{Tomioka Down-hole Array Station}
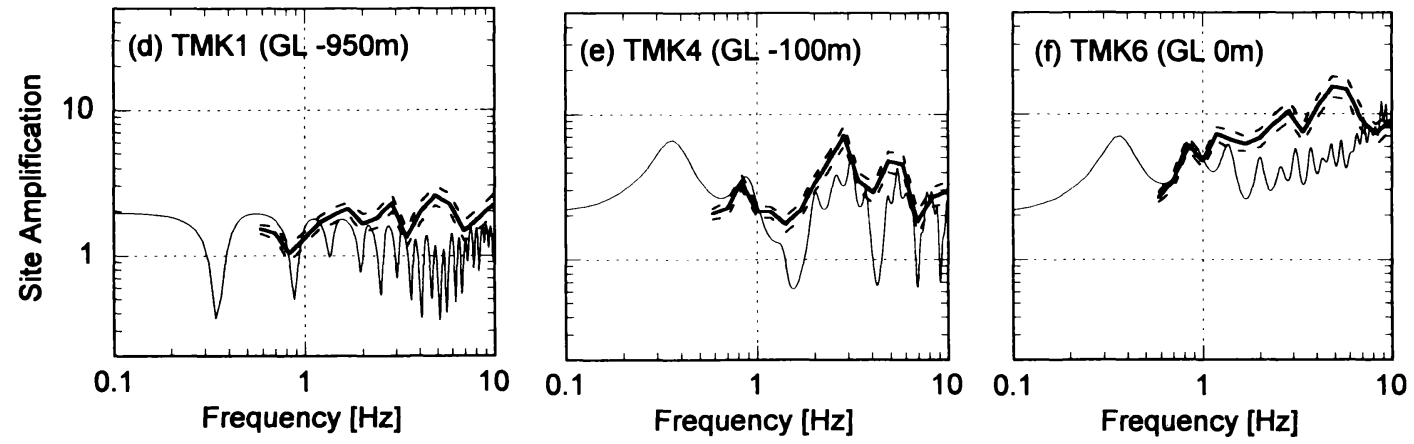

Fig. 8. Site amplification factors (thick lines) inverted at two borehole stations, IWK, (a) to (c), and TMK, (d) to (f), and their standard deviation (dashed lines). Thin lines indicate theoretical transfer functions from the bedrock to each observation point obtained by the one-dimensional multiple reflection theory of $\mathrm{SH}$-waves with incident angle of 0 degree.

8 に細実線で示す.インバージョン結果の地盤増幅率 は, 波動論による増幅率の山や谷, 例えば IWK の GL$330 \mathrm{~m}$ に見られる $1.2 \mathrm{~Hz}$ と $3 \mathrm{~Hz}$ の谷や $4 \mathrm{~Hz}$ のピーク 等, 特徵的な傾向は捉えており, 入射波に対する地震基 盤からの増幅率が評価されている.

伝播経路の $Q$ 值が既往の研究と整合すること, および 地盤増幅率が理論値と対応することより，観測記録から 分離された震源スペクトルの振幅レベルは妥当であると 考えられる.

\section{2 関東直下のやや深発地震}

同様の検討を関東直下のやや深発地震について行っ た. 拘束条件は, OGW の地盤増幅率と伝播経路の $Q$ 值 に対し, Fig. 3(b) と Fig. 7 の白丸に示すように与えた.

インバージョンで得られた加速度震源スペクトルを, 加速度に対応する地震モーメント密度関数 $\omega^{2} M(f)$ に变 換し，3 地震を例にとり Fig. 6(b) に示す. 図中の破線は (6) 式の $M_{0}-f_{c}$ 関係から定めた $\omega^{-2}$ モデルによる值で

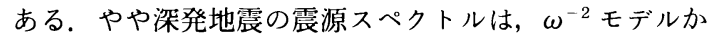
ら予測される值を上回っており, 震源での短周期スペク トルの励起が大きいことを示している. Fig. 6(b)には震 源のメカニズム解も示した. $§ 2$ で述べたように，南関 東直下のやや深発地震は様々なメカニズムの地震が混在 しているが, いずれのタイプも短周期スペクトルの励起 が大きい傾向にある.

検討に用いた観測点のうち，HMYでは地震基盤から 地表に至る地下構造が減衰も含めて評価されており［武 村・他 (1993)]，その地盤モデルを Table 4(c) に示す. また, TBT では表層 $50 \mathrm{~m}$ 部分は PS 検層から, 地震基 盤に至る深部構造はやや長周期微動のアレー観測 [山 中・他(1994)] から Table 4(d) に示す地盤モデルが推 定されている.ここで, 地盤の減衰は $h(f)=(1 / 2 Q(f))=$ $0.02 f^{-0.5}$ と仮定した。 これらの地盤モデルを基にして， 地震基盤からの伝達関数を 1 次元波動論を用いて計算 した.インバージョンで得られた地盤増幅率を一点鎖 
Table 4. Subsurface structure at (a) IWK, (b) TMK, (c) HMY, and (d) TBT. The models (a) to (c) are determined by Takemura et al. (1993), and the model (d) by Yамаnaka et al. (1994). Locations of observation points used in this study are also indicated by solid circles.

(a) IWK

\begin{tabular}{|c|c|c|c|c|c|c|}
\hline \multirow[t]{2}{*}{ Obs. points } & \multirow{2}{*}{$\begin{array}{c}\text { Depth } \\
\text { (a) }\end{array}$} & \multirow{2}{*}{$\begin{array}{l}\text { Thickness } \\
\text { (a) }\end{array}$} & \multirow{2}{*}{$\begin{array}{l}\text { Density } \\
\left(t / a^{3}\right)\end{array}$} & \multirow{2}{*}{$\begin{array}{c}\mathrm{Vs} \\
(\mathrm{a} / \mathrm{s})\end{array}$} & \multicolumn{2}{|c|}{ Damping: $h(f)=h_{0} f^{\alpha}$} \\
\hline & & & & & bo & $\alpha$ \\
\hline \multirow{3}{*}{$\mathrm{GL} 0 \mathrm{~m}$} & \multirow{2}{*}{0.0} & & & & & \\
\hline & & 0.6 & 1.60 & 357 & 0.1134 & 0.000 \\
\hline & \multirow[b]{2}{*}{21.1} & 20.5 & 1.95 & 1034 & 0.1134 & 0.000 \\
\hline \multirow{2}{*}{ GL-20m } & & 273.9 & 2.23 & 1345 & 0.0741 & -0.536 \\
\hline & 3 & 10.0 & 2.40 & 1761 & 0.0741 & -0.536 \\
\hline \multirow{2}{*}{ GL-330m } & & 25.8 & 2.50 & 2800 & 0.0741 & -0.536 \\
\hline & 330.8 & $\infty$ & 2.50 & 2800 & 0.0050 & 0.000 \\
\hline
\end{tabular}

(b) TMK

\begin{tabular}{|c|c|c|c|c|c|c|}
\hline \multirow[t]{2}{*}{ Obs. points } & \multirow{2}{*}{$\begin{array}{l}\text { Depth } \\
\text { (a) }\end{array}$} & \multirow{2}{*}{$\begin{array}{c}\text { Thickness } \\
\text { (a) }\end{array}$} & \multirow{2}{*}{$\begin{array}{l}\text { Density } \\
\left(t / a^{3}\right)\end{array}$} & \multirow{2}{*}{$\begin{array}{c}\mathrm{Vs} \\
(\mathbb{m} / \mathrm{s})\end{array}$} & \multicolumn{2}{|c|}{ Damping: $h(f)=h_{0} f^{\alpha}$} \\
\hline & & & & & ho & $\alpha$ \\
\hline \multirow{3}{*}{$\mathrm{GL} 0 \mathrm{~m}$} & 0.0 & & & & & \\
\hline & & 4.8 & 1.50 & 181 & 0.1539 & -1.000 \\
\hline & 4 & 95.1 & 1.58 & 573 & 0.1539 & -1.000 \\
\hline \multirow[t]{4}{*}{ GL- $100 \mathrm{~m}$} & 99.9 & 45.1 & 1.65 & 700 & 0.0086 & -0.334 \\
\hline & 145.0 & 325.0 & 1.73 & 930 & 0.0086 & -0.334 \\
\hline & & 360.0 & 1.95 & 1275 & 0.0240 & -0.334 \\
\hline & & 90.0 & 2.45 & 2208 & 0.0240 & -0.334 \\
\hline \multirow{2}{*}{ GL-950m } & 9500 & 30.0 & 2.55 & 2800 & 0.0240 & -0.334 \\
\hline & & $\infty$ & 2.55 & 2800 & 0.0050 & 0.000 \\
\hline
\end{tabular}

線で，1 次元波動論による結果を実線で Fig. 9(a)〜Fig. 9(d) に示す．両者の振幅およびピークや谷の振動数はほ ぼ対応しており，入射波に対する地震基盤からの増幅率 が評価されている.

\section{3 南関東の浅い地震}

同様の検討を主に伊豆の浅い地震について行った。 ンバージョン結果の震源スペクトルを Fig. 6(c) に示す. 拘束条件は 84.2 之同一である. 図の縦軸は $\omega^{2} M(f)$ に 変換してあり, 破線は (6) 式の $M_{0}-f_{c}$ 関係から定めた $\omega^{-2}$ モデルを示す．南関東で発生する浅い地震の震源ス

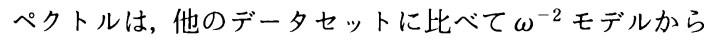
予測される值により近づく傾向にある．四中には震源の メカニズム解も示した．この地域で発生する地震は主に 横ずれ断層であるが，同じ横ずれ断層であってあ Fig. 6 (c) に示した左側二つの地震 S1 と S3 は同程度の短周期 の励起を示すのに対し, 右側の地震 S8 は励起が小さい. S1 と S8 は伊豆半島沖で, S3 は神奈川・山梨県境で発 生した地震であるため, 短周期励起の差が震央位置に依 存するとは考えにくい，むしろ， S8 の震源が $3 \mathrm{~km}$ とご く浅いのに対し，S1 とS3 は $10 \mathrm{~km}$ 以上であるため, 震源深さが短周期の励起に関係している可能性がある. この点については 55 にて述べる.

§ 4.2 にて実施したやや深発地震の検討により, HMY, TBT, OHJ, KDR, KHN-S, YMH-M の地盤增幅率 は既に得られている。 そこで, HMY, TBT の地盤増幅率 をFig. 9(a)〜Fig. 9(d) に重ねて示す. インバージョンで

\begin{tabular}{|c|c|c|c|c|c|c|}
\hline \multirow[t]{2}{*}{ Obs. points } & \multirow{2}{*}{$\begin{array}{l}\text { Depth } \\
\text { (a) }\end{array}$} & \multirow{2}{*}{$\begin{array}{l}\text { Thickness } \\
\text { (a) }\end{array}$} & \multirow{2}{*}{$\begin{array}{l}\text { Density } \\
\left(t / n^{3}\right)\end{array}$} & \multirow{2}{*}{$\begin{array}{c}\text { Vs } \\
(\mathrm{a} / \mathrm{s})\end{array}$} & \multicolumn{2}{|c|}{ Damping: $h(f)=h_{0} f^{\alpha}$} \\
\hline & & & & & & $\alpha$ \\
\hline \multirow[t]{9}{*}{ GL $0 \mathrm{~m}$} & 0.0 & & & & & \\
\hline & & 4.0 & 1.30 & 255 & 0.1674 & -0.315 \\
\hline & & 10.0 & 1.40 & 553 & 0.1674 & -0.315 \\
\hline & & 10.0 & 1.60 & 850 & 0.1674 & -0.315 \\
\hline & 24 & 12.0 & 1.90 & 793 & 0.1674 & -0.315 \\
\hline & 38 & 12.0 & 1.90 & 1020 & 0.1674 & -0.315 \\
\hline & & 4.0 & 1.80 & 510 & 0.1674 & -0.315 \\
\hline & 52 & 6.0 & 1.90 & 773 & 0.1674 & -0.315 \\
\hline & 58. & 62.0 & 1.90 & 716 & 0.2396 & -1.000 \\
\hline \multirow{4}{*}{ GL-120m } & 120 & 80.0 & 1.90 & 716 & 0.2396 & -1.000 \\
\hline & 200 & 270.0 & 2.00 & 800 & 0.0100 & 0.000 \\
\hline & 470.0 & 800.0 & 2.20 & 1600 & 0.0050 & 0.000 \\
\hline & 12700 & $\infty$ & 2.50 & 3000 & 0.0050 & 0.000 \\
\hline
\end{tabular}

\begin{tabular}{|c|c|c|c|c|c|c|}
\hline \multirow[t]{2}{*}{ Obs. points } & \multirow{2}{*}{$\begin{array}{l}\text { Depth } \\
\text { (a) }\end{array}$} & \multirow{2}{*}{$\begin{array}{c}\text { Thickness } \\
\text { (a) }\end{array}$} & \multirow{2}{*}{$\begin{array}{l}\text { Density } \\
\left(t / \mathbf{n}^{3}\right)\end{array}$} & \multirow{2}{*}{$\begin{array}{c}\mathrm{Vs} \\
(\mathbf{a} / \mathrm{s})\end{array}$} & \multicolumn{2}{|c|}{ Damping: $h(f)=h_{0} f^{\alpha}$} \\
\hline & & & & & ho & $\alpha$ \\
\hline \multirow[t]{7}{*}{ GL $0 \mathrm{~m}$} & 0.0 & & & & & \\
\hline & 17 & 1.7 & 1.60 & 60 & 0.0200 & -0.500 \\
\hline & 120 & 10.3 & 2.05 & 580 & 0.0200 & -0.500 \\
\hline & 16.0 & 4.0 & 1.95 & 440 & 0.0200 & -0.500 \\
\hline & 230 & 7.0 & 2.10 & 540 & 0.0200 & -0.500 \\
\hline & & 19.0 & 1.90 & 400 & 0.0200 & -0.500 \\
\hline & $\begin{array}{l}42.0 \\
50\end{array}$ & 8.0 & 1.80 & 476 & 0.0200 & -0.500 \\
\hline \multirow{4}{*}{ GL-50m } & 50.0 & 150.0 & 1.80 & 476 & 0.0200 & -0.500 \\
\hline & 200.0 & 800.0 & 1.90 & 889 & 0.0200 & -0.500 \\
\hline & 2300.0 & 1300.0 & 2.20 & 1225 & 0.0200 & -0.500 \\
\hline & & $\infty$ & 2.50 & 4245 & 0.0200 & -0.500 \\
\hline
\end{tabular}

得られた地盤增幅率と 1 次元波動論の振幅およびピー クや谷の振動数は良く対応しており，入射波に対する地 震基盤からの增幅率が評価されている，同様に， $\mathrm{OHJ}$, KDR, KHN-S, YMH-M の地盤増幅率の比較を Fig. 10(a)〜Fig. 10(d) に示す. 地盤が線型範囲内で挙動する 場合は, 震源特性や伝播経路の相違に拘わらず地盤增幅 率はほぼ一定と考えられる. Fig. 9 および Fig. 10 の地 盤増幅率の比較を見ると, $1 \mathrm{~Hz}$ 以上の振幅と卓越周期 は一致している地点が多く, 強震記録から安定した地盤 增幅率が評価されている。一方, $1 \mathrm{~Hz}$ 以下について見る 之, HMY を除く観測点のやや深発地震による地盤增幅 率は, 浅い地震に比べて系統的に大きい傾向にある. HMY は関東平野の縁に位置するのに対し，他の観測点 は関東平野内に位置するため, 観測点近傍の堆積層が影 響を及ぼしているのかむしれない，しかし，その理由は 現時点では明らかでないため, 以下の震源スペクトルの 議論は $1 \mathrm{~Hz}$ 以上を対象として進める.

\section{§5. 議論}

震源スペクトルの地域性を議論する方法として, 気象 
-.- Intermediate depth eq.

.......- Shallow eq.

1-D Theory

Higashi-Matsuyama Down-hole Array
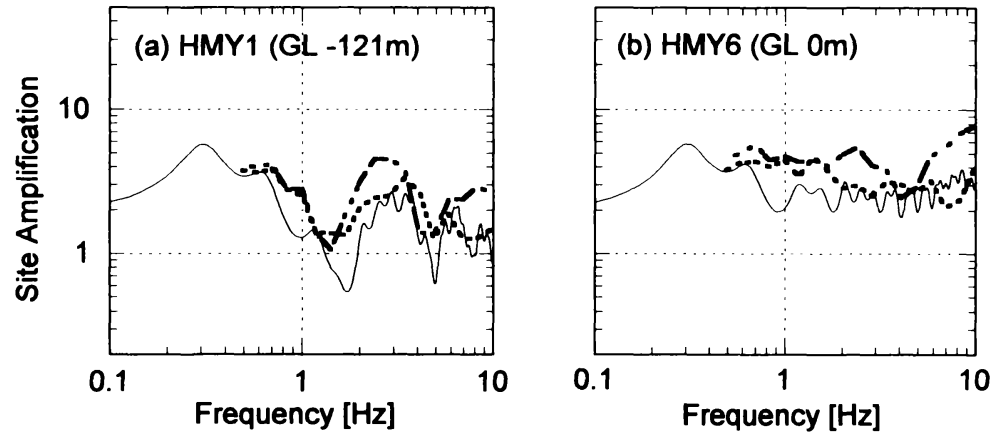

\section{Tobitakyu Down-hole Array}
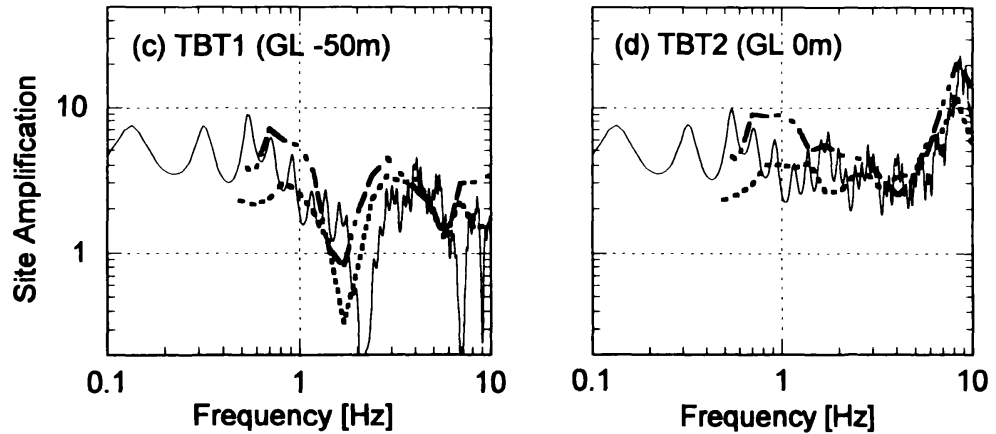

Fig. 9. Site amplification factors from intermediate depth earthquakes (dash-dotted-dotted lines) and from shallow earthquakes (dotted lines) inverted at two borehole stations, HMY, (a) to (b), and TBT,

(c) to (d). Thin lines indicate theoretical transfer functions.

庁マグニチュードを基準とする場合 [UTSU (1980)] と 地震モーメント $M_{0}$ を基準とする場合 [TAKEMURA et al. (1993)] が考えられる. 気象庁マグニチュードを決定し ている地震波は, 主にやや長周期の表面波であると言わ れている[例えば, 工藤 (1978)]. また, 内陸の浅い地震 と海溝沿いの地震では表面波の励起特性の違いにより, 同じ地震モーメントに対して決定されたマグニチュード の值が異なるという指摘もある [武村 (1990)]. さらに, マグニチュードの決定式そのあのが震源深さ $60 \mathrm{~km}$ を 境にして異なっている [勝又(1964)]. 一方, 断層のサイ ズ, すべり量, 剛性により決定される地震モーメントは 物理的にあ明快であり, 気象庁マグニチュードが示す震 源深さによる変動等も見られない. 従って, 地震モ一メ ントを基準に短周期震源スペクトルの振幅を見ることか ら議論を始める。

本研究で対象とした振動数帯域の加速度震源スペクト
ルは, Fig. 6(a)〜 (c) に示すように $1 \mathrm{~Hz}$ 以上は振動数に 依らずにほぼ一定と見なせる.そこで, $1 \mathrm{~Hz}$ から $10 \mathrm{~Hz}$ までの振幅を対数平均した值を短周期震源スペクトル振 幅 $M_{H F}$ と定義し, Table 1 に併記する. なお, 短周期の 震源スペクトルを支配するパラメータとして $f_{\max }$ [HANKS (1982)] があるが, 福島県沖の地震の $f_{\max }$ は約 $13.5 \mathrm{~Hz}$ に [S Атон et al. (1997)], 関東直下で発生する地 震の $f_{\max }$ は $7 \sim 8 \mathrm{~Hz}$ 以上 [KinoshiTA (1992)] と指摘さ れており, 対象とした $1 \sim 10 \mathrm{~Hz}$ の帯域では $f_{\max }$ の影響 は小さいと考えられる.

$M_{0}$ と $M_{H F}$ の関係をデータセットごとに整理して Fig. 11 に示す.震源スペクトルが $\omega^{-2}$ モデルに従うとすれ ば, $f \gg f_{c}$ のスペクトル振幅 $M_{H F}$ は (5) 式より,

$$
M_{H F}=\left(2 \pi f_{c}\right)^{2} M_{0}
$$

と表せる. $f_{c}$ とストレスドロップ $\Delta \sigma$ の関係 $\Delta \sigma[$ 例え ば, BRUNE $(1970,1971)]$ を (7) 式に代入すれば, $M_{H F}$ と 
-- Intermediate Depth eq. Shallow eq.
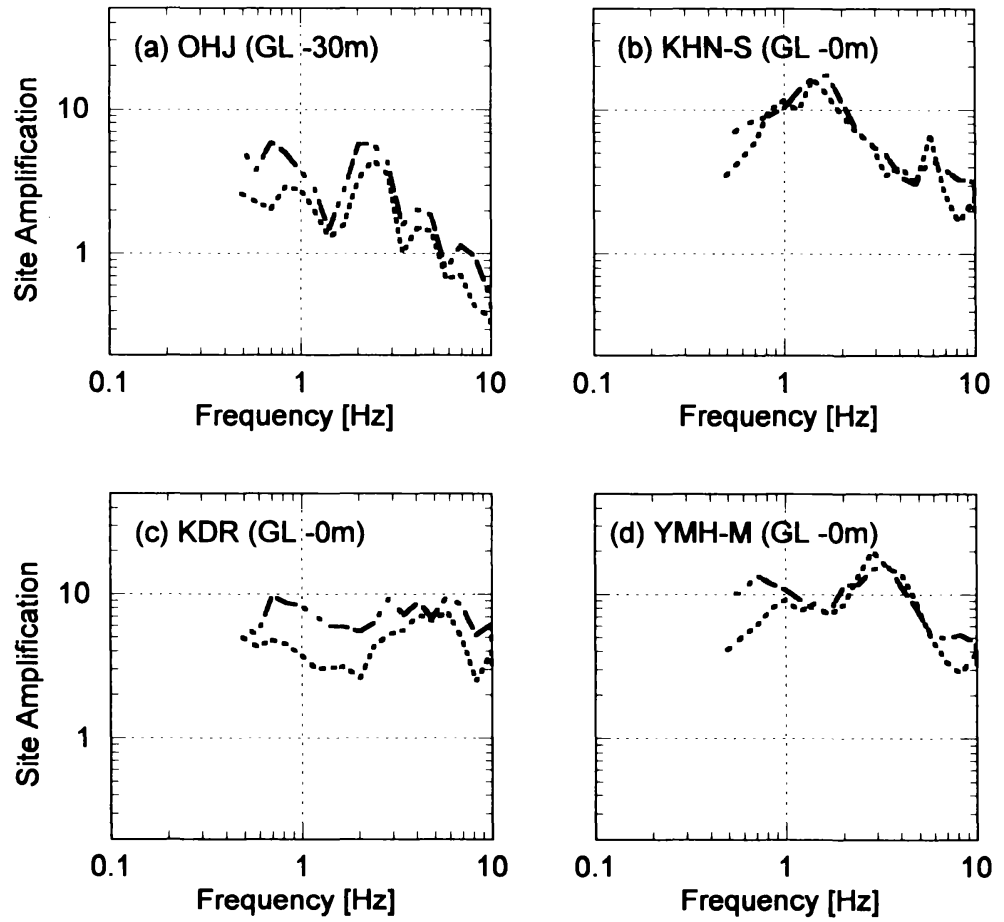

Fig. 10. Site amplification factors from intermediate depth earthquakes (dash-dotted-dotted lines) and from shallow earthquakes (dotted lines) inverted at four stations, (a) OHJ, (b) KHN-S, (c) KDR, and (d) YMH-M.

$M_{0}$ が $\Delta \sigma$ をして次式で表せる [例えば, ATKINSON and BERESNEV (1997)].

$$
M_{H F} \propto M_{0}^{1 / 3} \Delta \sigma^{2 / 3}
$$

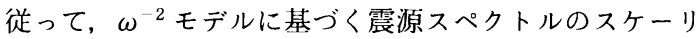
ングから見れば $M_{H F}$ は $M_{0}$ の $1 / 3$ 乗に比例することに なる. 本研究で得られた $M_{H F}$ と $M_{0}$ あこの関係をほぼ満 足しているが, 同じ $M_{0}$ に対する $M_{H F}$ の值はデータセッ トごとに異なっており, 地震の発生地域によって短周期 震源スペクトルの振幅に差が見られる， $M_{0}$ を基準に考 えると, ○で示した南関東の浅い地震, $\times$ の福島県沖の プレート境界地震, ○の関東直下のやや深発地震の順に $M_{H F}$ が大きくなる傾向があり， $\Delta \sigma$ が各地域で異なるこ とを示している.

短周期震源スペクトルの振幅 $M_{H F}$ は (8) 式からも明ら かなように， $M_{0}$ よりも $\Delta \sigma$ に強く支配される. そこで, 各地域で発生した地震の $\Delta \sigma$ を評価し比較する. $\Delta \sigma$ の 元々の定義は, すべり量 $u$ と断層長さ $r$ を用いて $\Delta \sigma \propto$ $u / r$ または $\Delta \sigma \propto M_{0} / r^{3}$ より導かれる静的な量である。 た $(7)$ 式から $(8)$ 式に変換するには, $\Delta \sigma \propto M_{0} / r^{3}$ の関係
に, $f_{c}$ と $\mathrm{r}$ の関係 $\mathrm{r}=$ const. $f_{c}^{-1}$ [例えば, BRUNE (1970, 1971), SATo and HiRASAwA (1973)] を代入して得られ るが, const. の值は仮定する震源モデルにより異なるた め, $\Delta \sigma$ はモデル依存のパラメータである. 本研究は BRUNE $の f_{c} \sim r$ 関係から導かれる(9) 式に $M_{0}$ と $M_{H F}$ を 代入して $\Delta \sigma$ を評価した。

$$
M_{H F}=\left(2.34 v_{s}\right)^{2}\left(\frac{7}{16}\right)^{-2 / 3} M_{0}^{1 / 3} \Delta \sigma^{2 / 3}
$$

このモデルを用いた理由は, Brune のモデルが既往の研 究で多く用いられており, 他の研究結果之の比較が容易 と判断したためである. 本研究で評価した $\Delta \sigma$ は (9) 式 から明らかなように，震源スペクトルの形状として $\omega^{-2}$ モデルを仮定した時の $M_{0}$ と $M_{H F}$ から定まる值であり, $\Delta \sigma$ の元々の定義とは異なる. また後述するように，震 源スペクトルがバンプを持つ場合は，バンプにより嵩上 げされた短周期のレベル $M_{H F}$ と $M_{0}$ から $\Delta \sigma$ が定まるこ とになり, 単純な $\omega^{-2}$ モデルに従う震源スペクトルから 定まる $\Delta \sigma$ とは意味が異なってくる．ここでは，あくま でも震源スペクトルの短周期レベルと地震モーメントを 


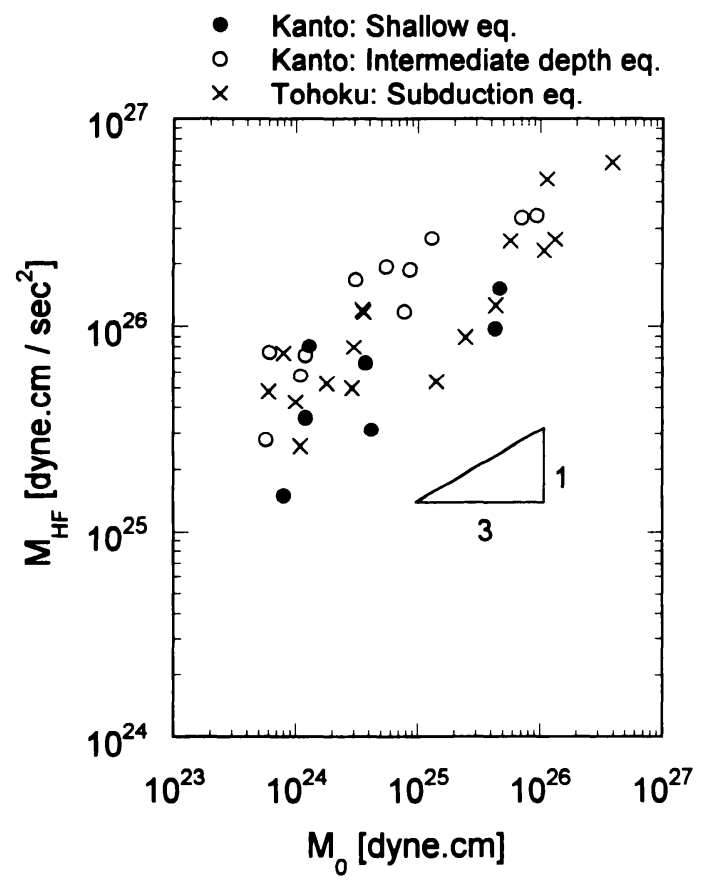

Fig. 11. Amplitude of source spectra in highfrequency range $M_{H F}$ versus seismic moment $M_{0}$. Solid circles, open circles, and crosses indicate shallow earthquakes in the southern Kanto region, intermediate depth earthquakes in the Kanto region, and subduction earthquakes off Fukushima Prefecture, respectively.

繫ぐパラメータとして $\Delta \sigma$ を位置づけ，震源での短周期 の励起強さを表す指標とする.

各地域で発生した地震の $\Delta \sigma$ を Fig. 12 と Table 1 に 示す. 図中には地域ごとの $\Delta \sigma$ の平均値と $\pm 1 \sigma$ あ示して いる. 各地域の $\Delta \sigma$ の平均值は, 南関東の浅い地震, 福 島県沖のプレート境界地震, 関東直下のやや深発地震の 順に強くなり, 約 100 bars, 200 bars, 370 bars の值が 得られた。短周期の振幅は (9) 式より $\Delta \sigma^{2 / 3}$ に比例する ため, やや深発地震は浅い地震に比べて 2.4 倍, プレー 卜境界地震は 1.6 倍はど短周期の励起が大きいことにな る. Kinoshita (1994b) は南関東直下のフィリピン海プ レート内で発生した浅い地震の $\Delta \sigma$ を求めている. その 平均值は 73 bars となり, 同地域で求めた本研究の結果 100 bars とほぼ整合している. 福島県沖のプレート境 界地震に対し, SATOH et al. (1997) は仙台市内の強震観 測点から, 武村・他 (1989) は IWK 観測点の主に速度記 録から $\Delta \sigma$ を求め, その平均值は約 200 bars になると 指摘している. 本研究の $\Delta \sigma$ とこれらの結果あ良く整合 している.なお，ここで引用した文献の $\Delta \sigma$ はすべて

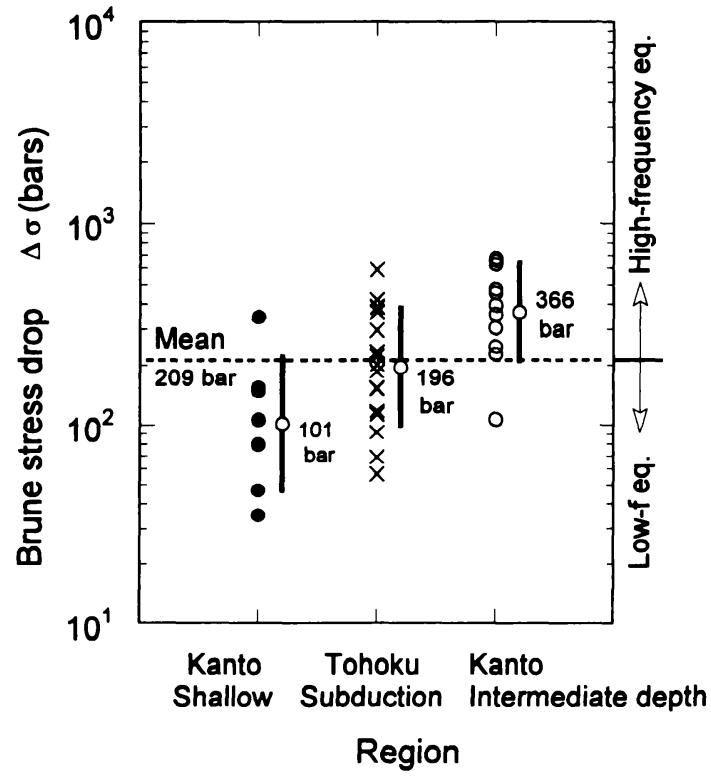

Fig. 12. Brune stress drop $\Delta \sigma$ estimated in each region. Vertical bars indicate the range of $\pm 1 \sigma$, and open circles on the bars indicate average of $\Delta \sigma$ in each region. Dotted line shows the average of $\Delta \sigma$ in the three regions. The events of which $\Delta \sigma$ is higher than the average, $\Delta \sigma=209$ bars, are classified into high-frequency earthquakes, while the events with lower than the average are classified into low-frequency earthquakes.

BRUNE の $f_{c} \sim r$ 関係を用いて評価された值であり，直接 の比較が可能である.

全地震に対する $\Delta \sigma$ の平均值は 209 bars となり, そ のレベルを Fig. 12 に破線で示す. やや深発地震の $\Delta \sigma$ は比較的ばらつきが小さく, いずれの地震む平均値以上 に $\Delta \sigma$ が大きい. 一方, 福島県沖の地震の $\Delta \sigma$ は差が見 られ, やや深発地震と同等の $\Delta \sigma$ 屯あれば, 浅い地震に 近い $\Delta \sigma$ あある.これらの地震の空間分布を見るため に, Fig. 12 に点線で示した $\Delta \sigma$ の平均值より大きい地 震を高周波地震, 小さい地震を低周波地震と分類して Fig. 13 に示す.このような大分類に従えば, 関東直下の やや深発地震はほとんどが高周波地震, 浅い地震は低周 波地震に属している. 一方, 福島県沖の地震は武村・他 (1989), 宇佐美・他 (1992) が指摘したように, 高周波 と低周波地震が空間的に分離されており, 短周期の励 起強さが地震の発生地域によって支配されている. TAKEMURA et al. (1993) は, 福島県沖の海溝沿いに発生 する $M>6$ の地震にはコーナー振動数が2つ $\left(f_{c}, f_{c}^{*}\right)$ 存 在し, 低振動数側の $f_{c}$ は (6) 式を満足するのに対し, 


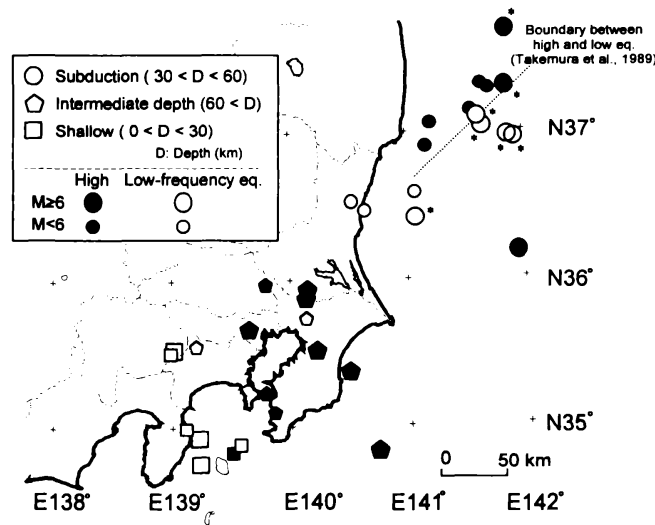

Fig. 13. Spatial distribution of high-frequency events (solid symbols) and low-frequency events (open symbols) defined in Fig. 12. The events with asterisk have spectral bump on source spectra [TAKEMURA et al. (1993)].

高振動数側の $f_{c}^{*}$ は $M_{0}$ に因らず約 $1 \mathrm{~Hz}$ で一定であ ると指摘している. $f_{\mathrm{c}}^{*}$ の存在は, 1993 年釧路沖地震 [MAHDAVIAN and SASATANi (1996)] や, 関東地方の フィリピン海プレートとアジアプレートの境界で発生し た地震 [KINOSHITA (1994b)] についても指摘されてい る. $f_{\mathrm{c}}^{*}$ は震源のアスペリティーの平均的な不均質サイズ に対応すると考えられている [TAKEMURA et al. (1993)]. 従って, $f_{\mathrm{c}}^{*}$ の存在により福島県沖の $M>6$ の地震の震源 スペクトルはバンプが生じ, 単純な $\omega^{-2}$ モデルに比べて 短周期レベルが嵩上げされることになる，福島県沖でバ ンプの存在が指摘された地震 [TAKEMURA et al. (1993)] を*印をつけて Fig. 13 に示す. TAKEMURA et al. (1993) によれば,バンプがない地震は比較的単純な波形を示 し，一つのアスペリティーが破壊された結果と考えられ るのに対し, バンプがある地震は複雑な波形を示してお り, 複数のアスペリティーが破壊された結果と推定され ており, 福島県沖の震源スペクトルが地域性を示すの は,アスペリティー強度の地域による違いを反映した結 果と解釈されている. つまり，バンプが存在する地震が 必ずしも高周波地震となるわけではなく, むしろ発生地 域のアスペリティーの性質によって高周波と低周波地震 が区別されるとしている. 本研究では, 解析対象振動数 の制限から全ての地震についてバンプの有無を検討する ことはできなかった. バンプの存在を調べることは, 震 源において短周期地震波が励起されるメカニズムを解明 することに繫がると思われ，今後検討すべき重要な課題 である.しかしながら, TAKEMURA et al. (1993) が指摘 するように, 短周期のレベルがバンプの有無に拘わらず

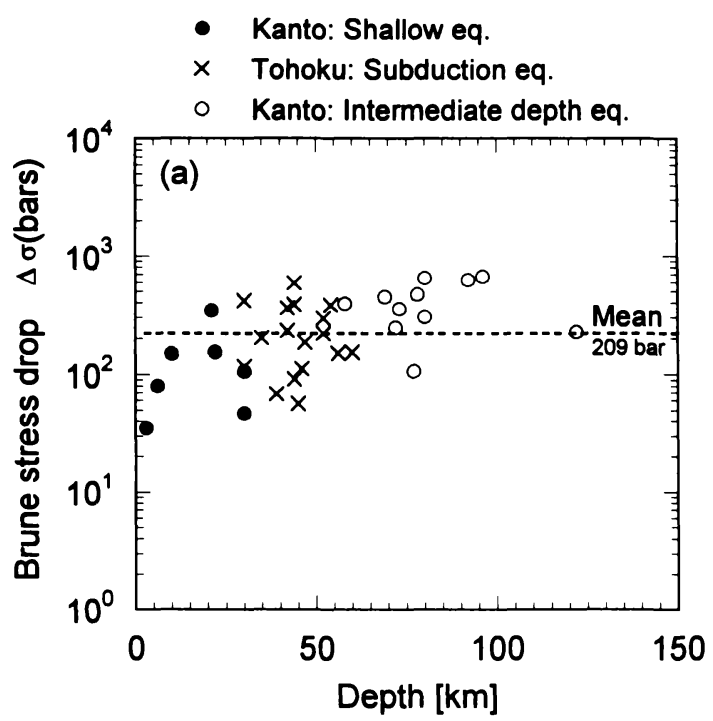

Fig. 14. Dependence of BRUne stress drop $\Delta \sigma$ on focal depth. Dotted line shows the average of $\Delta \sigma$ in the three regions.

アスペリティーの強度に依存するとすれば，本研究で求 めた $\Delta \sigma$ も間接的にアスペリティーの性質を反映した短 周期の励起強さを表す指標と思われる.

最後に, 震源深さをパラメータにとり, $\Delta \sigma$ の深さ依 存性を調べた結果を Fig. 14 に示す. 地震の発生地域 ごとに短周期の励起強さは異なるが, Fig. 14 に見ら れる傾向として, 震源が深い地震は浅い地震に比べて $\Delta \sigma$ が大きく, 短周期の励起が強いことが挙げられる. KinoshitA (1994b) は関東地方で発生した深さ $55 \mathrm{~km}$ 以浅の地震に対する apparent stress $\sigma_{\mathrm{A}}$ を評価し, $\sigma_{\mathrm{A}}$ は 深さに依存することを示している. MolAs and YAMAZAKI (1995) は, 国内全域で発生した深さ $200 \mathrm{~km}$ 以浅 の気象庁 87 型強震記録から, 震源深さを説明変数に入 れた最大加速度の距離減衰式を求めた。 その結果, 同じ マグニチュードと震源距離であっても, 最大加速度は震 源が深くなるほど増大し, その比例係数は $10^{0.0031 h}$ にな ると指摘している $(h$ は $\mathrm{km}$ 単位の震源深さ). 安中・他 (1987) は, 主に関東地方で発生した深さ $100 \mathrm{~km}$ 末満の 45 地震に対して最大加速度の距離減衰式を求め, 比 例係数 $10^{0.00671 h}$ を得ている. これらの比例係数を用い て最大加速度值の震源深さ依存性を概算すると, 深さ $100 \mathrm{~km}$ の地震は $0 \mathrm{~km}$ の地震に比べて $1.4 〜 4.7$ 倍ほよ゙ 最大加速度值が大きくなっている. 本研究で評価した $\Delta \sigma$ も深さ依存性を示しており, 震源深さは短周期の励 起に影響を与える重要なパラメータであると判断でき る. 


\section{§6. まとめ}

福島県沖のプレート境界地震, 関東直下のやや深発地 震, および南関東の浅い地震の加速度記録から振動数領 域の線形インバージョン解析 [岩田・入倉 (1986)] によ り震源スペクトルを各々求め, 地震の発生地域により短 周期波動の励起強さがよ゙の程度異なるかを検討した．使 用した強震記録は，40 地震に対して 27 地点で観測され た水平方向の計 672 波である.

インバージョン結果の $1 \mathrm{~Hz} \sim 10 \mathrm{~Hz}$ の加速度震源ス ペクトルの平均値から短周期の震源スペクトル振幅 $M_{H F}$ を評価した。 $\omega^{-2}$ モデルに基づく震源スペクトルの スケーリングから見れば $M_{H F}$ は地震モーメント $M_{0}$ の $1 / 3$ 乗に比例するが, 本研究で得られた $M_{H F}$ と $M_{0}$ むこ の関係をほぼ満足している，ただし，同じ $M_{0}$ に対する $M_{H F}$ の値は地震の発生地域によって異なる. その差を定 量的に見るために, BRUNE のモデルを用いて $M_{H F}$ と $M_{0}$ から $\Delta \sigma$ を求めた．各地域ごとに $\Delta \sigma$ を平均すると，南 関東の浅い地震は $\Delta \sigma=100$ bars, 福島県沖のプレート 境界地震は $\Delta \sigma=200$ bars, 関東直下のやや深発地震は $\Delta \sigma=370$ bars となり, やや深発地震は浅い地震に比べ て 2.4 倍, プレート境界地震は 1.6 倍ほど短周期の励起 が強いことを示す結果が得られた，以上のように地震の 発生地域ごとに短周期の励起強さは異なるが, 震源が深 い地震は浅い地震に比べて $\Delta \sigma$ が大きく, 震源深さは短 周期の励起に対して重要なパラメータであると判断でき る.

\section{謝辞}

本研究で使用した強震記録は, 電力中央研究所, 港湾 技術研究所, 東京大学生産技術研究所, 鹿島技術研究所 および 10 電力共通研究「地震観測にもとづく基準地震 動評価手法の研究」によって得られたあのである.これ らの貴重な記録を公開していただきました各機関と関係 者の方々に深く感謝致します.データセットの構築にあ たり，鹿島技術研究所の高橋克也博士には貴重なご意見 をいただきました. 2 名の匿名査読者の方々には丁寧に 原稿を読んで頂き，本稿の修正に大いに役立ちました。 謹んでお礼を申し上げます。

\section{文献}

AKI, K., 1980, Attenuation of shear-waves in the lithosphere for frequencies from 0.05 to $25 \mathrm{~Hz}$, Phys. Earth Planet. Interiors, 21, 50-60.

安中 正・山谷 敦・桃林治彦・野沢是幸, 1987, 関東 および周辺地域の地震観測記録を用いた基盤における 最大加速度推定式の検討, 第 19 回地震工学研究発表 会講演概要, 土木学会, 129-132.
Architectural Institute of Japan, 1992, Digitized strong-motion earthquake records in Japan, Vol. 1: The off east coast of Chiba Prefecture earthquake, December 17, 1987, Architectural Institute of Japan.

Atrinson, G. M. and I. Beresnev, 1997, Don't call it stress drop, Seism. Res. Lett., 68, 3-4.

Brune, J. N., 1970, Tectonic stress and the spectra of seismic shear waves from earthquakes, J. Geophys. Res., 75, 4997-5009.

Brune, J. N., 1971, Correction, J. Geophys. Res., 76, 5002.

Hanks, T.C., 1982, $f_{\max }$, Bull. Seism. Soc. Am., 71, 1867-1879.

日野幹雄, 1977 , スペクトル解析, 朝倉書店, 300 .

IsHidA, M., 1992, Geometry and relative motion of the Philippine Sea Plate and Pacific Plate beneath the Kanto-Tokai district, Japan, J. Geophys. Res., 97, 489-513.

岩田知孝・入倉孝次郎, 1986, 観測された地震波から震 源特性・伝播経路特性及び観测点近傍の地盤特性を分 離する試み, 地震 2, 39, 579-593.

KANAMORI, H., 1972, Mechanism of tsunami earthquakes, Phys. Earth Planet. Interiors, 6, 346-359.

KAто, K., 1994, Evaluation of local site effects on high frequency earthquake motion by an inversion method, Doctor Thesis, Tohoku University.

Kato, K., M. Takemura, T. Ikeura, K. Urao and T. Uetake, 1992, Preliminary analysis for evaluation of local site effects from strong motion spectra by an inversion method, J. Phys. Earth, 40, 175-191.

勝又 護, 1964, 深い地震の Magnitude を決める一方 法, 地震 $2,17,158-165$.

Kinoshita, S., 1992, Local characteristics of the $f_{\max }$ of bedrock motion in the Tokyo metropolitan area, Japan, J. Phys. Earth, 40, 487-515.

Kinoshita, S., 1994a, Frequency-dependent attenuation of shear waves in the crust of southern Kanto area, Japan, Bull. Seism. Soc. Am., 84, 1387-1396.

Kinoshita, S., 1994b, The dependence of apparent stress on tectonic setting and focal depth in the Kanto area, central Japan, 平成 5 年度科学研究費補 助金（総合研究 A) 研究成果報告書, 1-23.

小山順二, 1983, 伝播性破壊確率モデルと地震の震源ス ペクトル, 地震 2, 26, 225-235.

Koyama, J., M. TAkemura and Z. Suzuki, 1982, A Scaling model for quantification of earthquakes in and near Japan, Tectonophysics, 84, 3-16.

工藤一嘉, 1978 , 長周期構造物への地震入力に関連した 表面波の評価, 第 5 回日本地震工学シンポジウム, 273-280.

Mahdavian, A. and T. Sasatani, 1996, S-wave spectra from strong motion seismograms: Aource parameters and site response, J. Fac. Sci., Hokkaido Univ., Ser. VII (Geophysics), Vol. 10, No. 1, 1-19.

Molas, G. L. and F. Yamazakı, 1995, Attenuation of 
earthquake ground motion in Japan including deep focus events, Bull. Seism. Soc. Am., 85, 13431358.

表 俊一郎・大沢 㭌, 1980, アレー観測による岩盤の 強震地動に関する研究, 日本建築学会大会学術講演梗 概集, 37-38.

表 俊一郎, 1983, 鉛直アレー地震観測による地震動特 性に関する研究，日本建築学会大会学術講演梗概集, 381-382.

佐藤良輔, 1989 , 日本の地震断層パラメータ・ハンド ブック, 鹿島出版会, 390 .

Sato, T. and T. Hirasawa, 1973, Body wave spectra from propagating shear cracks, J. Phys. Earth, 21, 415-431.

SAToh, T., H. Kawase and T. SATo, 1997, Statistical spectral model of earthquakes in the eastern Tohoku district, Japan, based on the surface and borehole records observed in Sendai, Bull. Seism. Soc. Am., 87, 446-462.

澤田義博・佐々木俊二・矢島 浩, 1991, 岩盤上で観測 された加速度波形に基づく強地震動特性の検討, 電力 中央研究所報告, 総合報告: U23, 1-107.

震災予防協会, 1993, 強震動アレー観测 No. 1, 盰団法 人震災予防協会.

Sugito, S., 1993, Data processing and databases for strong motion records, Earthquake motion and ground conditions, Edited and published by AIJ.

武村雅之, 1990, 日本列島およびその周辺地域に起こる 浅発地震のマグニチュードと地震モーメントの関係, 地震 $2,43,257-265$.

武村雅之・小山順二, 1983, 低周波地震のスケーリング
モデル一津波地震と中小規模低周波地震の関係一, 地 震 $2,36,323-336$.

武村雅之・稗圃成人・池浦友則・植竹富一，1989，プ レートの沈み込み帯における中小規模地震の震源スペ クトルの地域性, 地震 2, 42, 349-359.

武村雅之・池浦友則・高橋克也 - 石田 寛・大島 豊, 1993, 堆積地盤における地震波減衰特性と地震動評 価, 日本建築学会構造系論文報告集, 第 446 号, 1-11.

Takemura, M., K. Kato, T. Ikeura and E. Shima, 1991, Site amplification of S-waves from strong motion records in special relation to surface geology, J. Phys. Earth, 39, 537-552.

Takemura, M., T. Ikeura and T. Uetake, 1993, Characteristics of source spectra of moderate earthquakes in a subduction zone along the Pacific coast of the southern Tohoku district, Japan, J. Phys. Earth, 41, 1-19.

土田 肇・山田进一郎・倉田栄一, 1967, 港湾地域強震 観測地点資料（その 1)，港湾技研資料，No. 34 .

海野徳仁・長谷川 昭, 1982, 東北日本弧における二重 深発地震面と発震機構, 地震 $2,35,237-257$.

宇佐美龍夫 - 濱松音蔵 - 久本壮一・渡邊 健 - 中村亮 一・植竹富一, 1992, 震度分布からみた東北日本の地 震の特性, 地震 2, 45, 339-351.

UTsu, T., 1980, Spatial and temporal distribution of low-frequency earthquakes in Japan, J. Phys. Earth, 28, 361-384.

山中浩明・武村雅之・石田 寛・池浦友則・野澤 貴 佐々木 透・丹羽正徳, 1994, 首都圈西部におけるや や長周期微動のアレイ観測と $\mathrm{S}$ 波速度構造の推定, 地 震 2, 47, 163-172. 